\title{
A numerical and experimental analysis of an integrated TEG- PCM power enhancement system for photovoltaic cells
}

\author{
J., Darkwa ${ }^{1}, J_{.,}$Calautit ${ }^{1}$, D., Du², G., Kokogianakis ${ }^{3}$ \\ ${ }^{I}$ Faculty of Engineering, University of Nottingham, Nottingham NG7 2RD, United Kingdom \\ ${ }^{2}$ Faculty of Science and Engineering, University of Nottingham Ningbo, Ningbo, China \\ ${ }^{3}$ Sustainable Buildings Research Centre, University of Wollongong, Australia
}

Corresponding author: J.Darkwa@nottingham.ac.uk

\begin{abstract}
Solar photovoltaic (PV) cells especially crystal silicon cells have witnessed a soaring installed capacity during past years. Research efforts have been made to increase the PV conversion efficiency and one direction is towards the cooling of PV systems since a higher PV temperature impairs its conversion efficiency. Phase change materials (PCM) capable of storing large amounts of latent heat are found to be effective on cooling PV cells while thermoelectric generators (TEG) which are solid waste heat converters can be used for converting the heat from PV into electricity. Therefore, this research investigates the concept of an integrated thermoelectric PCM system to enhance the PV efficiency. Theoretical investigations found that the TEGs had small power output due to small temperature difference under natural convection conditions. However, PCM was effective on hampering PV temperature increase during heat storage process. This research developed a numerical model for thermal simulations of the integrated system and has been validated by experimental results. The effect of various PCM thicknesses, conductivities and phase change temperatures were evaluated. The simulation results stressed the importance of high PCM conductivity for a thick PCM layer to reduce its insulation effect on the TEG and PV layers. Finally, the best thermal performance for the $\mathrm{PV} / \mathrm{TEG} / \mathrm{PCM}$ system was achieved with a $50 \mathrm{~mm}$ thick PCM layer with thermal conductivity of $5 \mathrm{~W} / \mathrm{mK}$ and a phase change temperature of $40-45^{\circ} \mathrm{C}$. Further optimisation and experimental evaluation are however being recommended towards the establishment of the full technical and scientific boundaries.
\end{abstract}

Keywords: CFD; phase change materials (PCMs); thermoelectric generators (TEGs) 


\section{NOMENCLATURE}

$C p \quad$ specific heat capacity $(\mathrm{J} / \mathrm{kgK})$

$E \quad$ electrical energy output $\left(\mathrm{W} / \mathrm{m}^{2}\right)$

$E_{p v} \quad \mathrm{PV}$ power output $\left(\mathrm{W} / \mathrm{m}^{2}\right)$

$E_{\text {teg }} \quad$ TEG power output $\left(\mathrm{W} / \mathrm{m}^{2}\right)$

$G \quad$ solar radiation $\left(\mathrm{W} / \mathrm{m}^{2}\right)$

$k \quad$ thermal conductivity $(\mathrm{W} / \mathrm{mK})$

$H \quad$ total internal energy $(\mathrm{J})$

$H_{l} \quad$ elemental latent heat (J)

$H_{s} \quad$ elemental sensible heat (J)

$\Delta h \quad$ change in latent heat enthalpy $(\mathrm{J} / \mathrm{kg})$

$h \quad$ convective heat transfer coefficient $\left(\mathrm{W} / \mathrm{m}^{2} \mathrm{~K}\right)$

$h_{1} \quad$ convective heat transfer coefficient for the exposed surface of the PV $\left(\mathrm{W} / \mathrm{m}^{2} \mathrm{~K}\right)$

$h_{2}$ convective heat transfer coefficient at the back surface of the PCM $\left(\mathrm{W} / \mathrm{m}^{2} \mathrm{~K}\right)$

$\Delta L \quad$ thickness of PCM layer (m)

$\Delta L_{p v} \quad$ thickness of the PV layer (m)

$\eta_{p v} \quad$ conversion efficiency of PV

$\eta_{\text {teg }}$ conversion efficiency of TEG

$\eta_{25^{\circ} \mathrm{C}} \quad$ conversion efficiency of $\mathrm{PV}$ at $25^{\circ} \mathrm{C}$

$\rho \quad$ density $\left(\mathrm{kg} / \mathrm{m}^{3}\right)$

$Q_{\text {conv }}$ convective heat transfer (W)

$\Delta T \quad$ temperature difference $(\mathrm{K})$

$T_{\text {cold }}$ temperature at the cold junction of TEG (K)

$T_{h o t}$ temperature at the hot junction of TEG (K)

$T_{g} \quad$ PV surface temperature (K)

$T_{l} \quad$ melting temperature $(\mathrm{K})$

$T_{p c m} \quad$ PCM back surface temperature (K)

$T_{p v} \quad$ PV back surface temperature (K)

$T_{s} \quad$ solidification temperature $(\mathrm{K})$

$T_{\text {teg }} \quad$ TEG back surface temperature (K)

$T_{\infty} \quad$ ambient temperature (K) 
$\mathrm{t} \quad$ time (s)

$Y \quad$ full latent heat of a complete phase change (J)

ZT figure of merit of TEG $\left(\mathrm{K}^{-1}\right)$ 


\subsection{INTRODUCTION}

The growth in global installed solar photovoltaic (PV) capacity over the past decade is an indication that PV systems are playing a major role in reducing current levels of energy consumption and carbon emissions [1]. However, PV cells do encounter overheating problems when operating under high temperatures which affect their power conversion efficiency and ultimately contribute to thermal degradation of the cells. For instance, the output power for crystalline PV cells could decline between $0.4 \% /{ }^{\circ} \mathrm{C}$ and $0.65 \% /{ }^{\circ} \mathrm{C}$ under high operating temperatures [2]. Which means power conversion efficiency of PV cells operating at say $65^{\circ} \mathrm{C}$ can be reduced by $1.6 \%-2.6 \%$ in comparison with an operating temperature of $25^{\circ} \mathrm{C}$.

To this end various thermal management devices for PV systems have been studied. For instance, the concept of using combined photovoltaic/thermal (PV/T) for recovering the waste heat from the PV module and using it for thermal applications was proposed and evaluated but found the conversion efficiency to be lower than two separate systems [3]. Yazdanifard and Ameri [4] conducted an extensive assessment of the exergetic performance on PV/T systems and found out that using nanofluids, concentrators and optical filters could improve the exergy efficiency of PV/T systems. Other cooling methods for PV systems have also been reviewed [5]. They included natural and forced air ventilation systems, hydraulic cooling systems, heat pipe cooling systems, phase change energy storage systems. Natural ventilation systems were found with limited cooling effects while forced air ventilation and hydraulic cooling systems need to consume additional power to run the PV system. Heat pipe systems were found to be mainly for concentrator PV (CPV) and require relatively large space for installations. Phase change materials (PCMs) have been reported to be effective in controlling PV temperatures but there are limitations in their heat transfer capabilities and most importantly, there is no re-use of the heat harvested from the PV system [6]. A thermoelectric generator (TEG) is regarded as an environmentally friendly solid-state heat engine that can convert waste heat into electricity by building up a temperature difference between its hot and cold side [7]. Several investigations using TEGs in converting waste heat from solar cells into electricity have been reported but with low energy conversion efficiencies [8-9]. The low power conversion efficiencies were due to unstable temperature difference between the hot and cold side of the TEGs and their cooling effects on PV cells were rarely studied. There is therefore the need for novel and innovative solutions hence the current investigation.

The concept is based on an integrated PV-TEG-PCM system for simultaneously moderating PV temperatures and converting the excess heat into power while using the PCM for stabilising the temperature difference across the TEG. To date, there is limited works on the analysis of performance of PV-TEG-PCM systems. Hence, the present work will carry out theoretical investigations to assess the efficiency and power output of the proposed device. A prototype of the integrated PV/TEG/PCM system will be developed and tested in a controlled environment. Previously developed Paraffin based n-octadecane MEPCM will be utilised for the development of the integrated system to enhance heat transfer capability. The melting temperature and latent heat value of the MEPCM will be characterised using laboratory tests to assess integration with the PV-TEG-PCM system. The experimental tests will compare the performance of the PV-TEG-PCM with a standard PV and PV/TEG to assess the capabilities of the proposed system in curbing the temperature rise in the PV. Thermal modelling and simulation of the developed PV/TEG/PCM system will also be conducted and validated using the experimental data to assess the reliability of the model for future works. The validated approach will be used to assess the effect of different levels of solar radiation, different cooling strategies for the bottom surface and the different thickness of the PCM layer. 


\subsection{LITERATURE REVIEW}

PV cells have undergone development from first generation to third generation. The first generation is crystal silicon wafer-based cells. The second-generation cells are mainly thin film cells e.g. $\mathrm{CdTe}, \mathrm{Cu}(\mathrm{In}, \mathrm{Ga}) \mathrm{Se}_{2}$ (CIGS) and amorphous silicon solar cells. The third-generation cells are multi-junction cells e.g. Si nanostructured tandems. However, crystal silicon-based PV cells account for more than $80 \%$ of the recent market due to its mature manufacturing technique and low cost [10].

High cell temperature impairs the conversion efficiency of silicon cells. Iliceto and Vigotti [11] investigated a large PV power plant and summarized factors causing PV conversion loss. The temperature dependence of the solar cell performance was identified as one of the most important characteristics affecting the power output with losses up to $7.6 \%$.

In terms of thermal management techniques applied to PV, a range of different systems have been studied. Natural ventilation for cooling was identified with heat spreader or used in PV façade systems [12]. There are several literatures [13] on topics of PV/T but they are focused more on the performance of simultaneous utilization of solar thermal and electrical energy rather than on the cooling effect for PV. For forced air ventilation [14], additional power is required to drive a fan, etc. De-ionized liquid immersion cooling [15] and jet impingements [16] have both been reported for achieving good cooling performances of CPV. The drawback is that the systems need to run on additional power and mainly the applications are for cooling high temperature CPVs. Heat pipes [17] for PV systems have mainly been reported for CPV systems but require a relatively large space for installations. This is because a heat pipe needs a temperature difference across its two sections to drive the evaporation/condensation cycle and heat dissipation on the condensation section also requires a large heat exchange area.

The review by $\mathrm{Du}$ et al. [5] found PCMs to be relatively effective for regulating PV temperatures with their passive heat storage features. However, the waste heat stored in the $\mathrm{PCM}$ is rarely utilized in comparison with PV/T system. Low thermal response and crystalline segregation in PCM systems have been reported, although can be moderated by inserting fins or other techniques [18], they still imply innovative PCM system designs are required to circumvent these problems. Another study was carried out by Hasan et al. [19]. They utilized PCM in a building integrated PV (BIPV) system and was able to maintain a temperature reduction of $18{ }^{\circ} \mathrm{C}$ for 30 minutes. A theoretical study using microencapsulation phase change material (MEPCM) on a flat plate PV was also carried out by Ho et al. [20] by examining the performance of the MEPCM under different climate conditions. They achieved temperature reduction of $2^{\circ} \mathrm{C} / 5^{\circ} \mathrm{C}$ with corresponding PV efficiency increase of $0.13 \% / 0.42 \%$ for the summer and winter periods respectively. Stropnik and Stritih [21] carried out theoretical and experimental evaluation of a PV/ PCM panel cooling system. Their results showed that the system was able to reduce the maximum surface temperature to about $35.6{ }^{\circ} \mathrm{C}$ as compared with a PV without a PCM panel. Theoretical simulation results also showed an average increase of $7.3 \%$ in power production. Investigation by Chandela and Agarwalb [22] in the use of PCM cooling system also resulted in an increase of 5\% in electrical efficiency.

The temperature of the solar cells increases by absorbing the solar irradiation, hence solar PV cells can be a good heat source for TEGs. TEGs have been widely reported to be applied in a range of systems. However, since the conversion efficiencies are relatively low, their applications are less of an economic benefit. Even though these drawbacks restrict application into few areas, the development progress in using them as generators and efficient heat exchangers have bolstered the promise of TEG devices for waste heat recovery conversion applications [23-24]. In multiple reported PV/TEG applications, TEGs were directly attached to the back surfaces of both CPV and flat plate PV cells. In addition, heat sinks were attached 
to the TEG cold sides [25]. The temperature difference $\triangle \mathrm{T}$ over the TEG was of the order of $30-40{ }^{\circ} \mathrm{C}$, the electrical efficiency provided with this TEG was around $1 \%$ with Thermoelectric Figure of Merit $(\mathrm{ZT})=0.7$ but with $\mathrm{ZT}=4$, the system efficiency increased to $4.1 \%$ through extrapolation.

Amatya and Ram [26] adopted 66× suns parabolic concentrators, and a system efficiency of 3\% was measured for a commercial $\mathrm{Bi}_{2} \mathrm{Te}_{3}$ TEG module with $1.8 \mathrm{~W}$ output at an average temperature of $446 \mathrm{~K}$. Olsen et al. [27] undertook a research on solar thermoelectric generators (STEGs) with the goal to achieve conversion efficiency greater than $15 \%$. The prototype adopted a nanostructured $\mathrm{Bi}_{2} \mathrm{Te}_{3}$-based alloy with an effective $\mathrm{ZT}=1.03$ at the optimum operating temperature $\left(100^{\circ} \mathrm{C}\right)$. The high optical concentration reached 200-300 Suns at the absorber surface and the TEG hot side temperature reached $1000^{\circ} \mathrm{C}$. They however achieved a much lower efficiency of 5\% and was attributed to low temperature drop and the limitations of the ZT of the TEG material. Sark [28] proposed a PV/TEG hybrid system by attaching thermoelectric generators to the back of PV modules. Efficiency calculations based on an idealized model showed that by employing present day thermoelectric materials with figure of merits (ZT) of $0.004 \mathrm{~K}^{-1}$ at $300 \mathrm{~K}$ could lead to efficiency enhancements of up to $23 \%$ for roof integrated PV/TEG modules. Li et al. [29] demonstrated a similar PV/TEG hybrid system for a wireless sensor network. The hot sides of TEGs were attached to the rear of a PV panel to absorb the heat, and a heat sink was affixed to the cold side of the TEGs for heat dissipation. The TEGs were able to deliver power to the sensor network with a temperature difference of $5 \mathrm{~K}$.

Recently, Cui et al. [30] showed that PCM can supress the effect of the solar irradiance fluctuation on a PV-TE system and maintain optimal operating temperature. The study did not include a full validation of the PV-TEG-PCM system but did focus on the material properties of the modules. The work of Kazemian et al. [31] used PCMs with PVTs which reduced the surface temperature from $51.5^{\circ} \mathrm{C}$ to $58.78^{\circ} \mathrm{C}$ and coolant outlet temperature in comparison with PVT system. The works [31-32] carried out experimental work and sensitivity analysis of a solar PV/thermal system with phase change material. In a recent review, Babu and Ponnambalam [34] compared the electrical performance of different PV-TEG configurations with standalone PV systems and found that the PV-TEG systems included in their review produced $8 \%$ to $38 \%$ more electricity than the equivalent standalone PV systems. Two additional recent reviews have also highlighted the benefits and limitations of PV-TEG systems and provided a comprehensive overview of the current state-of-the-art in this area $[35,36]$.

The above reviews have shown that $\mathrm{PV} / \mathrm{PCM}$ system is effective in regulating $\mathrm{PV}$ temperatures, but lacks waste heat utilization facility. On the other hand, a PV/TEG system was found to be able to convert waste heat from PV into electricity, but the cooling effect on PV cell was rarely investigated. Furthermore, there is very limited work done on the experimental analysis of performance of PV-TEG-PCM systems. In addition, no study has investigated the impact of different levels of solar radiation, different cooling strategies for the bottom surface and the different thickness of the PCM layer on PV-TEG-PCM systems. Therefore, this study will carry out theoretical and experimental investigations of the performance of a PV/TEG/PCM system and compare it with a standard PV and PV/TEG systems. It aims to find the energy output separately from PV cells and TEGs and probes into the effect of the employment of PCM from simulation results derived from theoretical models. The model will be validated using the experimental data to assess the reliability of the model for future works. 


\section{METHODOLOGY}

\subsection{Physical model of PV/TEG/PCM}

Fig. 1 shows a schematic view of the proposed PV/TEG/PCM system. It consists of TEG modules combined with a PCM layer and firmly attached to the back of the PV panel. The PCM layer is meant to provide a stable temperature difference for the TEG whereas the TEG is supposed to convert any excess heat into power. For the benefit of this theoretical analysis, a 5W mono-crystal silicon PV panel (TDB 62.5*125/7-36-P, Nbsolar China) measuring $250 \mathrm{~mm} * 180 \mathrm{~mm} * 4.5 \mathrm{~mm}$ thick was chosen for this study. The rated efficiency is $12 \%$ at standard test condition (irradiance $1000 \mathrm{~W} / \mathrm{m}^{2}$, module temperature $25^{\circ} \mathrm{C}, \mathrm{AM}=1.5$ ). To enhance the heat transfer capability of the system, a $5 \mathrm{~mm}$ thick non-deformed PCM developed by Darkwa et al. [37] was adopted for the proposed system.

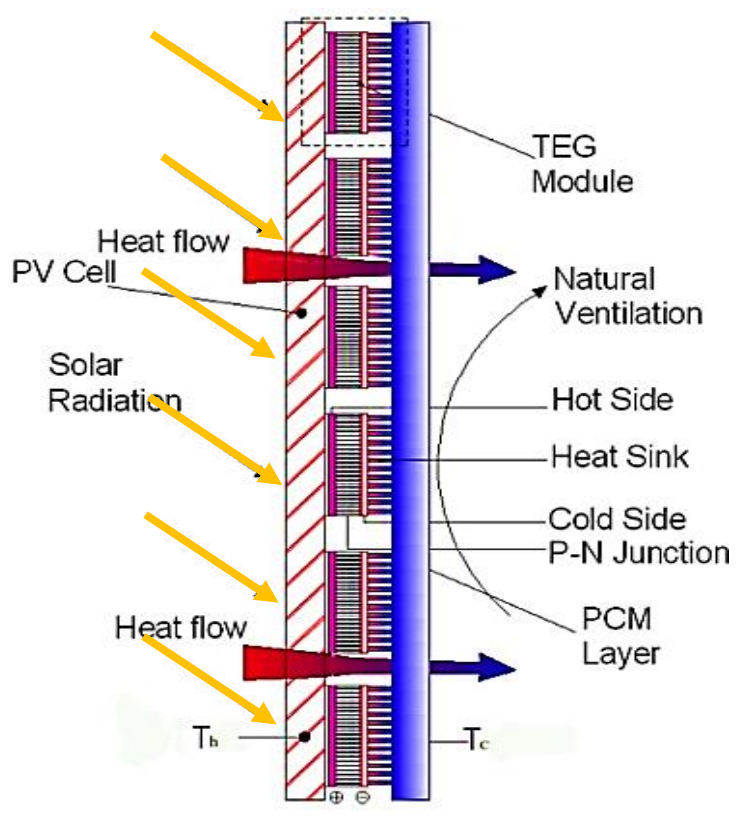

Figure 1: Physical arrangement of the PV-TEG-PCM system

\subsection{Energy modelling of PV/TEG/PCM system}

The physical model for the PV/TEG/PCM system was developed, as detailed in Fig. 2. The PV module was divided into two parts, a $3 \mathrm{~mm}$ glazing layer and a $1.5 \mathrm{~mm}$ silicon layer. The PV layer was treated as equivalent to a composite layer, consisting of $0.5 \mathrm{~mm}$ ethylene vinyl acetate (EVA) layer, $0.2 \mathrm{~mm}$ silicon layer, $0.5 \mathrm{~mm}$ EVA layer and $0.3 \mathrm{~mm}$ Tedlar ${ }^{\circledR}$ backsheet. TEG module was divided into three parts as a $2 \mathrm{~mm}$ thermoleg layer sandwiched between two identical ceramic layers, each of $0.5 \mathrm{~mm}$ thick. The arrangement of the thermoelectric element (P-N pair) is schematically shown in Fig. 3. There are 254 single thermoelectric elements each measuring $2 * 2 \mathrm{~mm}$ and contained in a $40 * 40 \mathrm{~mm}$ TEG cell. There is also an air gap between each thermoelectric element. The area covered by the $\mathrm{P}-\mathrm{N}$ pair is $10.16 \mathrm{~cm}^{2}$, giving an area ratio of $63.5 \%$ over the $16 \mathrm{~cm}^{2}$ cell area. Commercially available TEG cells were integrated into the back surface of the PV module. It should be noted that the thermal conductivity of the thermoelectric element is an effective value [29], which has already accounted for the influence of Peltier and Thomson effects. The non-deformed PCM layer was attached to the cold side of the TEG cells, thus forming an integrated thermoelectric PCM system (PV/TEG/PCM system). The thickness of the PCM layer is variable but a $5 \mathrm{~mm}$ thickness was utilised for the simulation as shown in Tab. 1. 


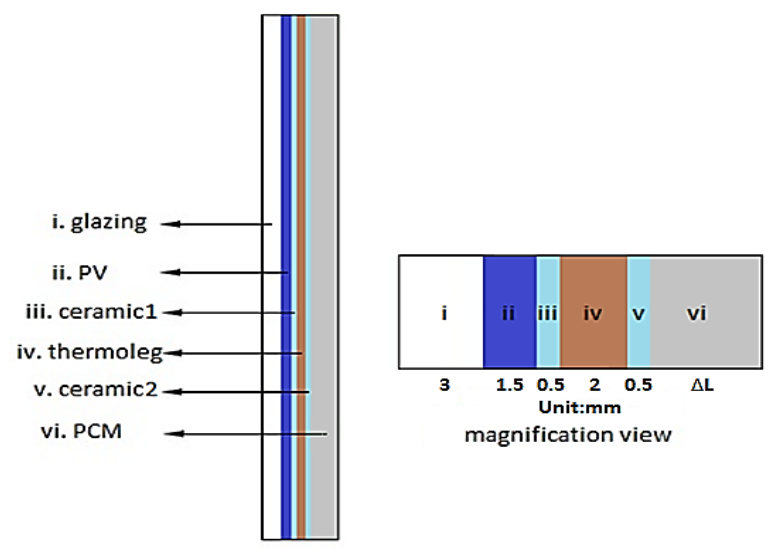

Figure 2: Physical model of the PV/TEG/PCM system

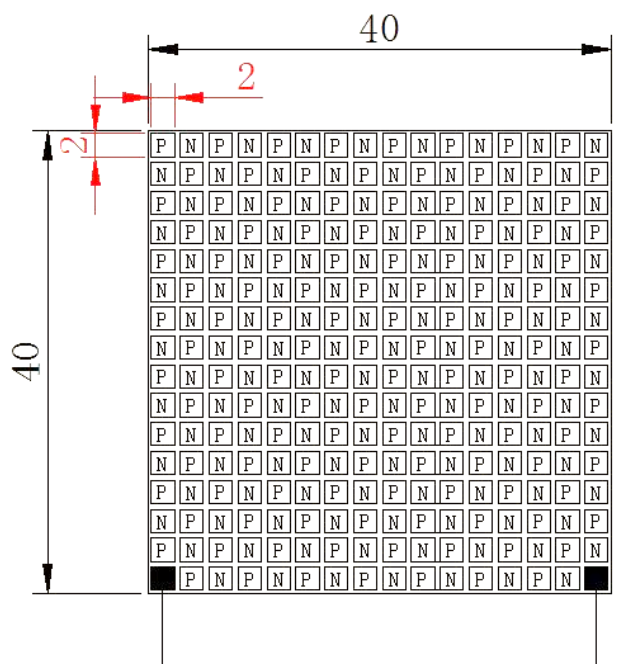

Figure 3: P-N thermoleg structure within TEG cell

Table 1: PV/TEG/PCM module material properties [37-40]

\begin{tabular}{|c|c|c|c|c|c|}
\hline Layer & $\begin{array}{c}\text { Thermal } \\
\text { conductivity, } \\
\text { W.m } \mathbf{m}^{-1} \mathbf{K}^{-1}\end{array}$ & $\begin{array}{l}\text { Density, } \\
\text { kg.m }{ }^{-3}\end{array}$ & $\begin{array}{c}\text { Heat } \\
\text { capacity, J.kg- } \\
{ }^{1} \mathbf{K}^{-1} \\
\end{array}$ & $\begin{array}{l}\text { Latent heat } \\
\text { J. } \mathbf{~ k g}^{-1}\end{array}$ & $\begin{array}{c}\text { Phase change } \\
\text { temperature } \\
\text { range K }\end{array}$ \\
\hline PV & 0.2894 & 1190 & 1552 & - & - \\
\hline Glass & 0.98 & 3000 & 500 & - & - \\
\hline EVA & 0.23 & 960 & 2090 & - & - \\
\hline $\mathrm{Si}$ & 148 & 2330 & 677 & - & - \\
\hline Tedlar $^{\circledR}$ & 0.36 & 1200 & 1250 & - & - \\
\hline Ceramic & 25 & 3720 & 880 & - & - \\
\hline TEG & 0.92 & 92.74 & 708.4 & - & - \\
\hline $\begin{array}{l}\text { Non-deformed } \\
\text { MEPCM }\end{array}$ & 0.215 & 749 & 2000 & 125000 & $298-300$ \\
\hline
\end{tabular}


Figure 4 shows the energy pathway for the PV/TEG/PCM system. The PV module receives solar radiation on the front surface and converts part of it into electric power. The solar radiation contributes to the sensible heating of the PV module and the internal energy while having convection heat exchange on both surfaces with the ambient. The remaining heat is conducted to the TEG to produce the electric output by building up a temperature difference across the hot and cold surfaces with the aid of the PCM layer.

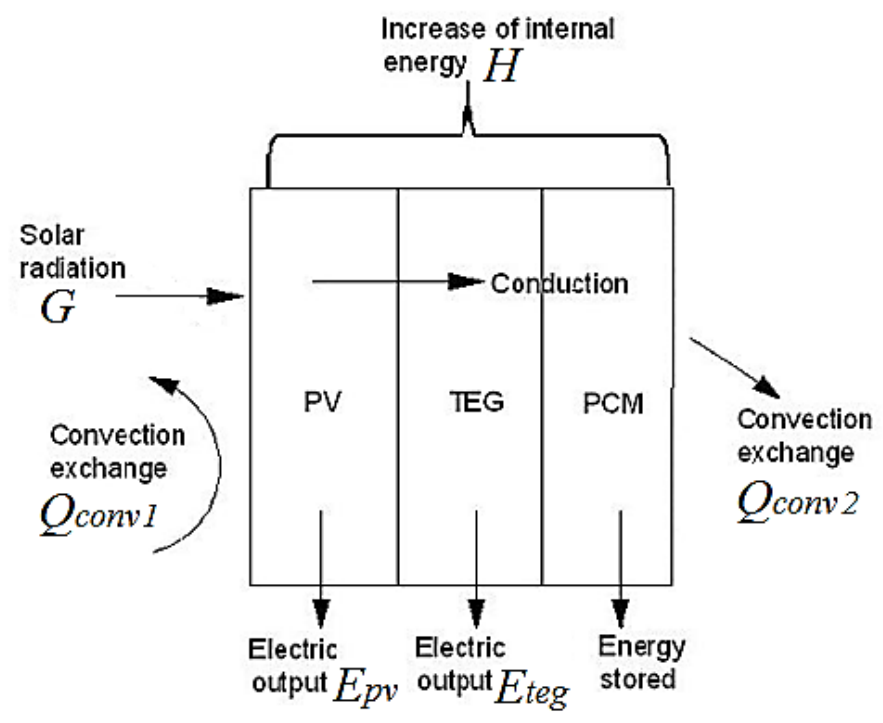

Figure 4: Energy pathway in the PV/TEG/PCM system

The general assumptions for the modelling were as follows:

1. PV: The reflection of the radiation on the glazing surface was $3 \%$, and the absorption of solar radiation by glazing layer was neglected. The emitted longwave radiation from the glazing surface was neglected. All the transmitted solar radiation was assumed to be absorbed by PV silicon layer. PV conversion efficiency was expressed as a function of cell temperature based on a referenced efficiency at a $25^{\circ} \mathrm{C}$ in a laboratory condition.

2. TEG: The thermoelectric material properties were constant. The thermal resistance and electric resistance of the P-N junction point were negligible. The MEPCM layer was a complete homogeneous layer. Contact resistance between the PV back surface and the TEG ceramic layer was neglected.

3. PCM: Liquid and solid phases of the PCM were considered as isotropic and homogeneous. Thermo-physical properties were assumed to be constants in each phase. Contact resistance between the PCM layer and the TEG ceramic layer was neglected.

The general energy equation for the system is presented as:

$$
G=E_{p v}+E_{t e g}+H+Q_{c o n v}
$$

$\mathrm{E}_{\mathrm{pv}}$ is the electrical output from the PV and it is given as [35]:

$E_{p v}=\tau_{g} \cdot \alpha_{c e l l .} G . \eta_{p v}$

Where $\mathrm{G}$ is the solar radiation flux incident on the system, $\tau_{g}$, is the glass cover transmissivity and $\alpha_{c e l l}$. is the cell absorptivity. 
Based on the assumption No. $1, \tau_{g}$ becomes 0.97 and $\alpha_{c e l l}=0$. Therefore, the electrical output from the PV may be as expressed below as:

$E_{p v}=0.97 G \times \eta_{p v}$

The conversion efficiency of PV $\left(\eta_{\mathrm{pv}}\right)$ is given in relation to $\mathrm{PV}$ at $25^{\circ} \mathrm{C}\left(\eta_{25^{\circ} \mathrm{C}}\right)$ and its back surface temperature $\left(T_{p v}\right)$ as [41]:

$\eta_{p v}=\eta_{25^{\circ} \mathrm{C}}-0.08 \%\left(T_{p v}-25\right)$

$E_{t e g}$ is the electrical output from TEG and may also be expressed as a function of $\eta_{p v}$ as [42]:

$$
E_{t e g}=0.97 G *\left(1-\eta_{p v}\right) * \eta_{t e g}
$$

The conversion efficiency of TEG cells $\eta_{\text {teg }}$ is, given as [35]:

$$
\eta_{\text {teg }}=\left(1-T_{\text {cold }} / T_{\text {hot }}\right) \times \frac{\sqrt{1+\mathrm{ZT}_{\text {teg }}}-1}{\sqrt{1+\mathrm{ZT}_{\mathrm{teg}}}+T_{\text {cold }} / T_{\text {hot }}}
$$

$\mathrm{T}_{\text {cold }}$ and $\mathrm{T}_{\text {hot }}$ are the temperatures at the cold and hot junction of TEG respectively, $\mathrm{T}_{\text {teg }}$ is the average temperature of the thermoleg layer and $\mathrm{ZT}_{\text {teg }}$ is taken as a common value achieved by the commercial TEG products [28].

The total internal energy $(\mathrm{H})$ consist of both the sensible $\left(\mathrm{H}_{\mathrm{s}}\right)$ and latent heat $\left(\mathrm{H}_{\mathrm{l}}\right)$ storage components

$H=H_{s}+H_{l}$

$\mathrm{H}_{\mathrm{s}}$ and $\mathrm{H}_{\mathrm{l}}$ can also be expressed as:

$$
\begin{array}{r}
H_{s}=\rho \times \Delta L \times C p \times \Delta T \\
H_{l}=\rho \times \Delta L \times \Delta h
\end{array}
$$

Where $\Delta \mathrm{T}$ is the temperature increase, $\rho$ is the density, $\Delta L$ is the thickness and $C p$ is the heat capacity of the PCM layer.

$\Delta \mathrm{h}$ is a function of liquid fraction $\mathrm{v}$ with the expression as shown below:

$\Delta h=v \cdot Y$

$v=\left\{\begin{array}{cc}0 & \text { if } \mathrm{T}<\mathrm{T}_{\mathrm{s}} \\ \frac{\mathrm{T}-\mathrm{T}_{\mathrm{s}}}{\mathrm{T}_{1}-\mathrm{T}_{\mathrm{s}}} & \text { if } \mathrm{T}_{\mathrm{s}}<\mathrm{T}<\mathrm{T}_{\mathrm{l}} \\ 1 & \text { if } \mathrm{T}>\mathrm{T}_{\mathrm{l}}\end{array}\right.$

Where $\mathrm{Y}$ is full latent heat of a complete phase change, $T_{\mathrm{s}}$ is the solidification temperature, $\mathrm{T}_{1}$ is the melting temperature of a PCM [43].

The convective heat transfer at the surface of the $\operatorname{PV}\left(Q_{\text {conv } 1}\right)$ and at the back of the PCM $\left(Q_{\text {conv2 }}\right)$ may be summarized as:

$Q_{\text {conv }}=\left(Q_{\text {conv } 1}+Q_{\text {conv } 2}\right)=h_{1} \times\left(T_{g}-T_{\infty}\right)+h_{2} \times\left(T_{p c m}-T_{\infty}\right)$ 
Where $T_{g}, T_{p c m}, T_{\infty}$ are PV surface temperature, PCM back surface temperature and the ambient temperatures respectively, $h_{1}$ and $h_{2}$ are the convective heat transfer coefficients for the exposed surface of the PV and the back surface of the PCM respectively.

\subsection{Numerical thermal simulations}

For the benefit of comparison, commercial software ANSYS FLUENT was used to develop a three-dimensional model and simulate the temperature profiles for three systems, i.e. the standard $P V$ system, the $P V / T E G$ system and the $P V / T E G / P C M$ system under different solar radiation conditions. Based on the temperature profile of the PV back surface and the solar radiation level, the PV efficiency and power output can be projected. Considering the temperature profiles on both TEG hot and cold sides as well as the heat flux through TEG hot side, the TEG efficiency and power output can also be projected.

The computational domain and mesh for the system are shown in Figure 5. Figure 5a shows the dimensions of the PV/TEG/PCM system. The influence of different PCM thickness was investigated between $2.5 \mathrm{~mm}$ to $20 \mathrm{~mm}$. The boundary conditions were set for the front and bottom surfaces while the side surfaces were treated as symmetry walls. For each simulation, ambient temperature (free stream temperature at 293K) was set. Solar irradiation on the front surface and the heat convection coefficients for the front and bottom surfaces were set accordingly. The value was varied to simulate three difference cooling strategies: natural air, forced air and water. The influence of different solar radiation levels was investigated between $400-1000 \mathrm{~W} / \mathrm{m}^{2}$. The boundary conditions for the three systems were set identical at each time. The material properties of each layer of the module were set based on the values shown in Table 1. The CFD code used the Finite Volume Method (FVM) approach. The second order upwind method has been used to discretise the convection terms. For the solidification/melting model of the PCM, and enthalpy-porosity technique is used in FLUENT. This technique does not explicitly track the melt interface and the liquid fraction is associated with each cell in the domain and utilised to indicate the cell volume fraction that is in liquid form. The governing equations are not detailed here but fully available from the FLUENT Theory guide.

Using a full hexahedral mesh structure of a maximum size of $0.004 \mathrm{~m}$ and a minimum size of $0.00004 \mathrm{~m}, 24,900$ cells were produced, and the mesh was deemed satisfactory following a grid sensitivity analysis as detailed in Figure $5 \mathrm{c}$-d. The mesh sensitivity analysis was performed by using three grids with different grid resolutions and by comparing the temperature values for three locations: PV back, TEG back and PCM back. The analysis showed that the variations between the three mesh sizes: coarse at 8,505, medium at 24,900 and fine at 78,750 elements, were insignificant ranging from $0.001-0.003^{\circ} \mathrm{C}$.

A transient solver is utilised to solve the numerical equations. The effects of the time steps were examined, and 60s (total of 300-time steps, max 20 iterations per time step) was determined as a reasonable time step. In each simulation, convergence of the solution was checked at each time step, with the convergence criterion of $10^{-6}$ for the energy equation. The validation of the modelling work with experimental data is detailed in Section 4.8. 


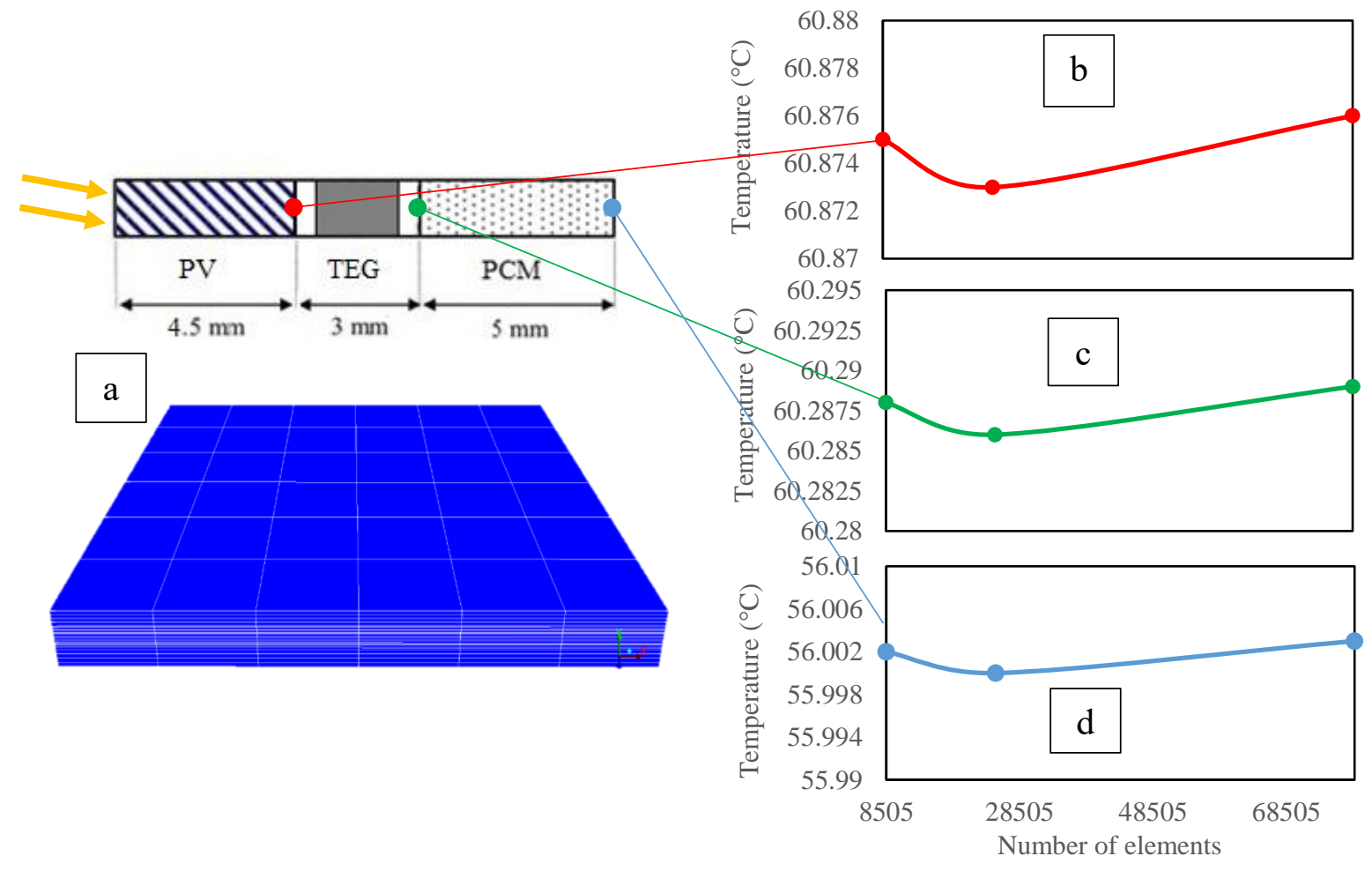

Figure 5: (a) Mesh for the PV/TEG/PCM system; mesh analysis for temperature of (b) PV back (c) TEG back and (d) PCM back

\section{4: Experimental method}

\subsubsection{PV/TEG arrangement}

A $5 \mathrm{~W}$ mono-crystal silicon PV panel (TDB $62.5^{*} 125 / 7-36-\mathrm{P}$ ) of size $250 \mathrm{~mm} * 180 \mathrm{~mm} * 4.5 \mathrm{~mm}$ (Length*Width*Thickness) was acquired from Nbsolar China. The rated efficiency is $12 \%$ at standard test condition (irradiance $1000 \mathrm{~W} / \mathrm{m}^{2}$, module temperature $25{ }^{\circ} \mathrm{C}, \mathrm{AM}=1.5$ ). The PV/TEG/PCM was designed based on this PV module. Fig. 6 illustrates how the TEG cells were arranged at the back of the PV module. In order to cover adequate area of the PV back surface, a total number of 22 pieces of Bismuth Telluride TEG cells (Size of 40mm*40mm*3mm, TEC1-12706, Xianghe orient electronics, China) were closely arranged in series for high voltage generation. To avoid any possible malfunctioning each TEG cell was initially tested before attaching them to the back side of the PV with thermal conductive grease.

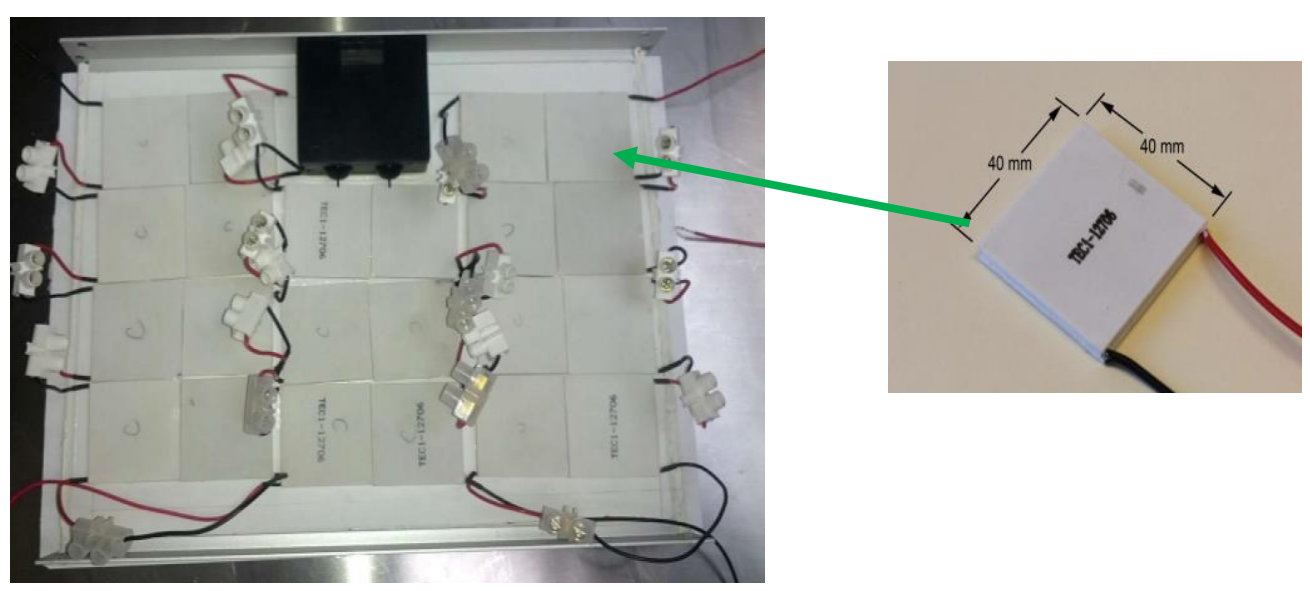

Figure 6: PV/TEG arrangement 


\subsection{2: MEPCM characterisation}

The n-Octadecane MEPCM was selected and obtained from Woodge Shanghai Company and was mainly based on its melting temperature, relatively high heat storage capacity and market availability. To verify its structural integrity, Scanning Electron Microscopy (SEM) test was conducted on a sample. As shown in Fig. 7, the result confirmed that the MEPCM was of good encapsulation efficiency and without any sign of structural deformation to the particles.

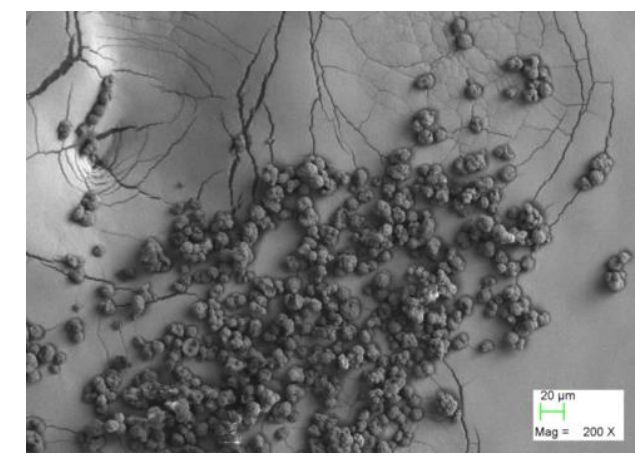

Figure 7: Scanning Electron Microscopy (SEM) test result

Differential scanning calorimetry (DSC) test was also carried out on a sample to confirm its true melting temperature and energy storage capacity. SII DSC 6220 testing machine was adopted to carry out the test for the MEPCM sample. Based on ISO 11357 procedure: Initially, $5 \mathrm{mg}$ of MEPCM sample was loaded into one of the aluminium pans whilst the other one was kept as a reference pan. The testing temperature was set between $5^{\circ} \mathrm{C}$ and $50{ }^{\circ} \mathrm{C}$ a heating rate of $2{ }^{\circ} \mathrm{C} /$ minute and then held for 5 minutes in order to achieve a stable curve. DSC curves were analysed to obtain the melting temperature (onset of the peak) and melting enthalpy (integration of the DSC signals) of the sample. The test results show a latent heat value of 123 $\mathrm{kJ} / \mathrm{kg}$ and a melting temperature range of $25.78-31.28{ }^{\circ} \mathrm{C}$ thus confirming that the acquired PCM meets the selection criteria. From Fig. 8, the latent heat was obtained as $123 \mathrm{~kJ} / \mathrm{kg}$ with a melting temperature range of $25.78-31.28{ }^{\circ} \mathrm{C}$ thus confirming the selection criteria of the MEPCM. 


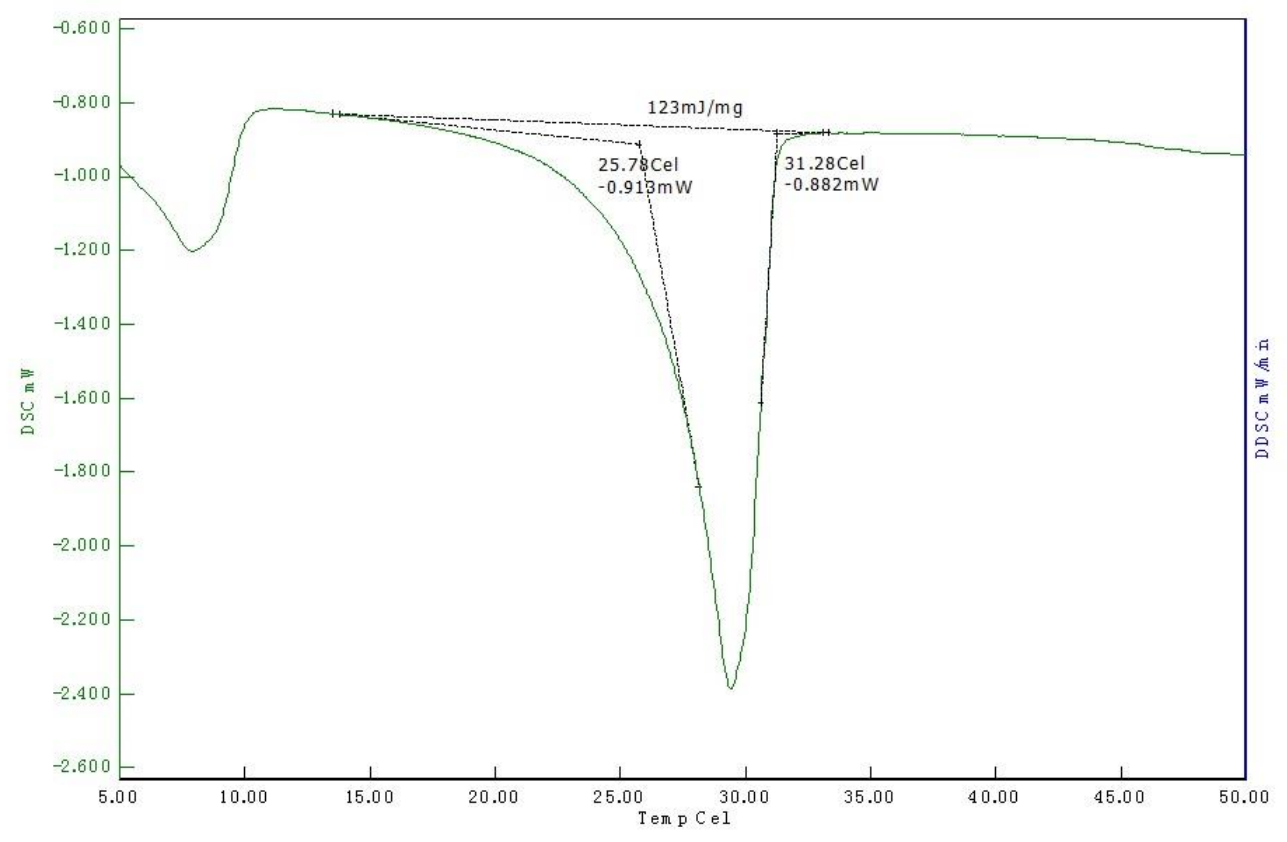

Figure 8: Differential scanning calorimetry (DSC) test results

\subsection{3: Fabrication of MEPCM tablet}

The size of the MEPCM tablet was designed to be identical to the TEG cell for the ease of integration. A metal die mould shown in Fig. 9a and measuring $40 \mathrm{~mm} * 40 \mathrm{~mm}$ was specifically made for the fabrication of the MEPCM tablets. The design adopted $5 \mathrm{~mm}$ as an appropriate thickness, therefore each tablet occupies a volume of $40 \mathrm{~mm} * 40 \mathrm{~mm} * 5 \mathrm{~mm}=8 \mathrm{~cm}^{3}$. The density of a referenced MEPCM tablet using the same material is $749 \mathrm{~kg} / \mathrm{m}^{3}$ [44], therefore the mass of each piece of the $5 \mathrm{~mm}$ compacted MEPCM tablet should be $8 \mathrm{~cm}^{3 *} 0.749 \mathrm{~g} / \mathrm{cm}^{3}=6 \mathrm{~g}$. Hence, a hydraulic pressing machine shown in Fig. $9 \mathrm{~b}$ was used to produce a total of twenty-two (22) pieces of non-deformed MEPCM tablets (see sample tablet in Fig. 9c) at a recommended pressure of $2.8 \mathrm{MPa}$ [44]. Furthermore, the thermal conductivity of the sample tablet was tested with a KD2 Pro Thermal Properties Analyzer to obtain an enhanced value of $0.215 \mathrm{~W} / \mathrm{mK}$ ( $\pm 10 \%$ accuracy, $0.10-6 \mathrm{~W} / \mathrm{mK}$ range).

(a)

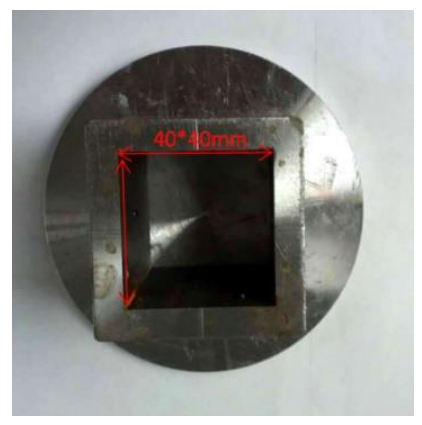

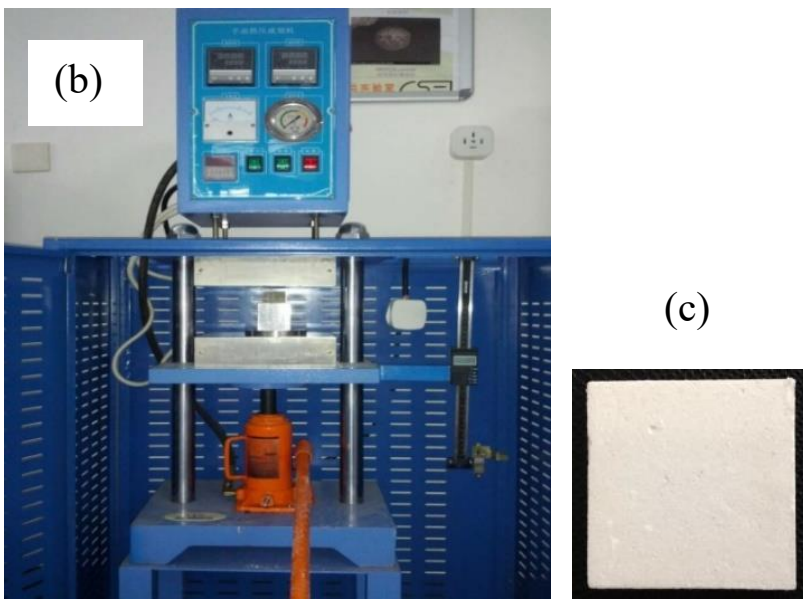

Figure 9: (a) Metal mould; (b) Hydraulic press; (c) MEPCM tablet 
After assembling the PV/TEG system, the MEPCM tablets were carefully attached to the back of the TEGs with silicon adhesive before firmly securing them into position with aluminium adhesive tape as shown in Fig. 10. Respective K type thermocouples (Omega TT-K-30-SLE) and a heat flux sensor (Omega, HFs-04) were then fixed in appropriate positions to measure the relevant data as tabulated in Table 2. It should be mentioned that measurement at the back of the Tedlar sheet is a convenient way of obtaining the PV back surface temperature [44].

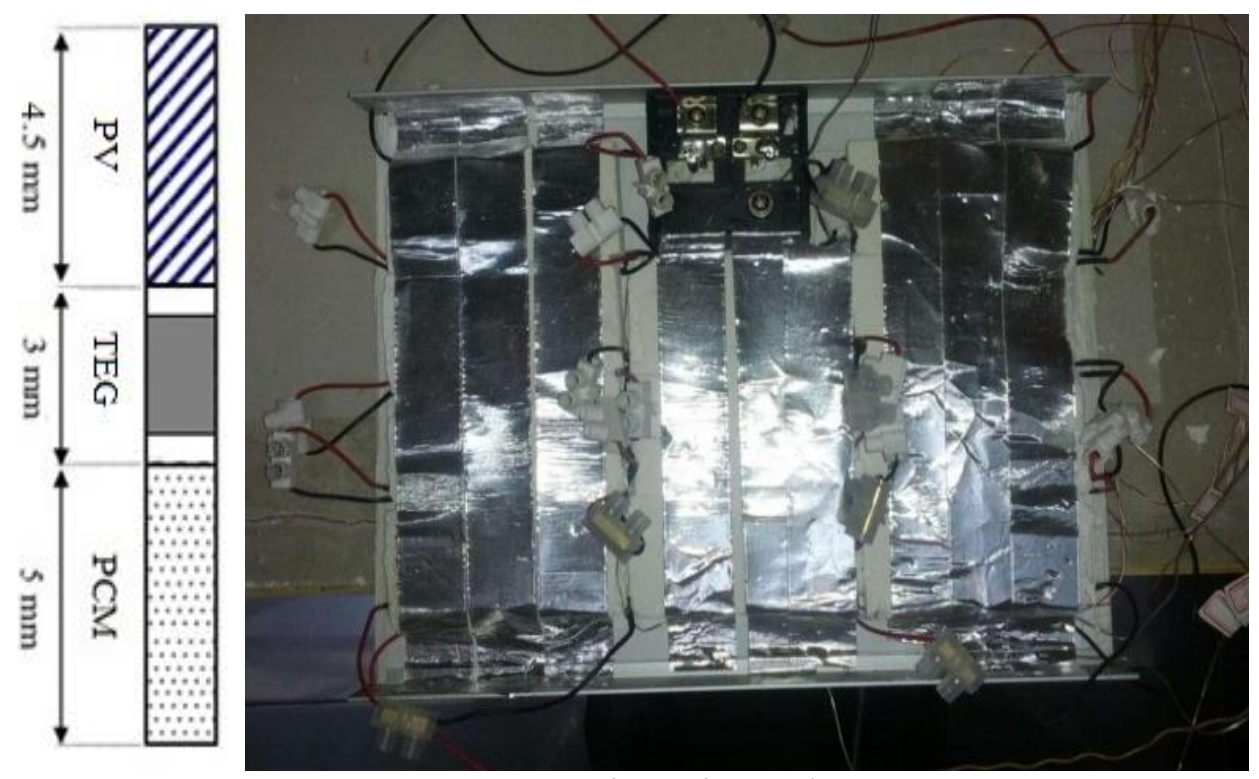

Figure 10: PV/TEG/PCM layout

Table 2: Locations of thermocouples

\begin{tabular}{lll}
\hline Sensor & Location & Measurement \\
\hline Thermocouple 1 & $\begin{array}{l}\text { PV/TEG } \\
\text { interface } \\
\text { TEG/PCM } \\
\text { Thermocouple 2 }\end{array}$ & $\begin{array}{l}\text { Temperature on TEG hot side } \\
\text { Temperature on TEG cold } \\
\text { side }\end{array}$ \\
Thermocouple 3 & $\begin{array}{l}\text { PCM back } \\
\text { surface }\end{array}$ & $\begin{array}{l}\text { Temperature on PCM back } \\
\text { surface }\end{array}$ \\
Thermocouple 4 & In the air & Ambient Temperature \\
Thermocouple 5 & Junction box & $\begin{array}{l}\text { TEG open circuit voltage } \\
\text { output }\end{array}$ \\
Heat flux sensor & $\begin{array}{l}\text { TEG/PCM } \\
\text { interface }\end{array}$ & \\
&
\end{tabular}

\subsection{5: Test procedure}

The experimental test rig is shown in Figure 11. It mainly consists of a test chamber, an air conditioning $(\mathrm{A} / \mathrm{C})$ unit and a data logging system. The outer envelope of the test chamber was made from an insulated wooden panel measured $120 \mathrm{~cm}$ x $83 \mathrm{~cm}$ x $120 \mathrm{~cm}(\mathrm{~L} \mathrm{x} \mathrm{W} \mathrm{x} \mathrm{H})$ whereas gypsum board was used for the inner envelop. To minimise heat gain, the glass door to the chamber was fully insulated with a $3 \mathrm{~cm}$ thick polystyrene foam. The fan coil cooling unit of the $\mathrm{A} / \mathrm{C}$ unit was located inside the test chamber but was controlled from outside the chamber. A $500 \mathrm{~W}$ halogen lamp (PVF135-500, Philips) was installed inside the chamber as a solar 
simulator. The PV/TEG/PCM unit was placed on top of a platform with its surface facing directly to the lamp. A pyranometer (LP02 Hukseflux, $<1.8 \%$ uncertainty) was also mounted on the surface of the PV/TEG/PCM module to measure the irradiation given by the light. The initial internal temperature was stabilised at $20^{\circ} \mathrm{C}$ with the aid of the $\mathrm{A} / \mathrm{C}$ cooling unit before the data collection exercise was started. The air temperatures and heat flux were respectively measured with a set of calibrated thermocouples (Omega K-type thermocouple Neoflon PFA TT-K-30-SLE, $\pm 1.1^{\circ} \mathrm{C}$ ) and thin film heat flux sensors (Omega HFS-04, $\pm 0.5 \mathrm{~W} / \mathrm{m}^{2}$ ) through a data logger (type Agilent 34970A + 20 channel multiplexer 34901A) and a dedicated computer.

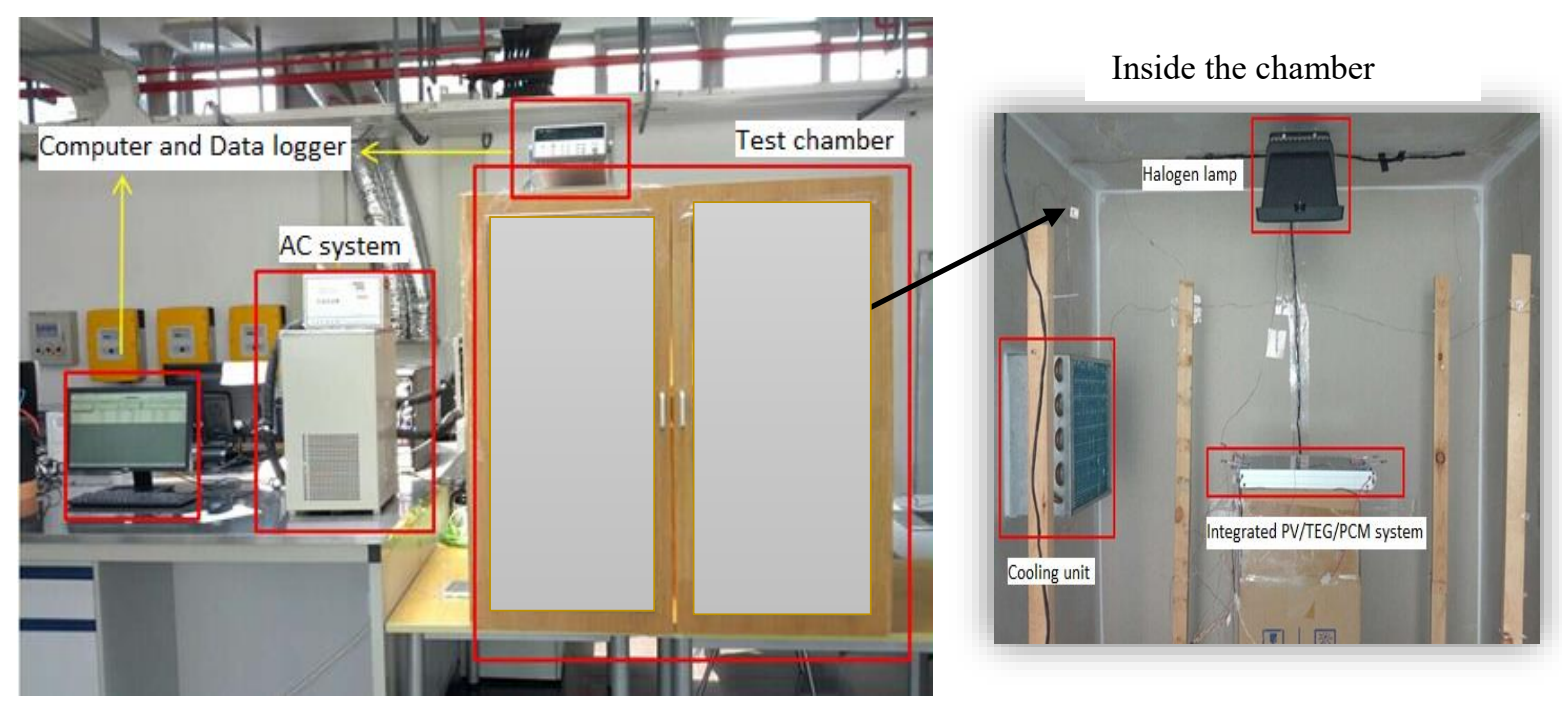

Figure 11: The test rig arrangement

\subsection{RESULTS AND DISCUSSION}

\subsection{Theoretical temperature profile}

The PV temperatures were plotted under four levels of solar radiation as indicated in Fig. 12 with $T_{1}, T_{2}, T_{3}$ referring to temperatures of the standard PV, the PV/TEG and the PV/TEG/PCM systems respectively. Analysis of the results show that even though the level of solar radiation influences the peak PV temperatures, the standard PV and PV/TEG systems displayed similar temperature profiling for the same radiation levels. The PV/TEG/PCM system however performed much better and was able to maintain lower peak temperature values within the first 1.5 hours irrespective of solar radiation levels. The PV back surface temperature $\left(\mathrm{T}_{\mathrm{pv}}\right)$ was also observed to be higher than the other systems and was attributed to the insulation effect of the PCM layer. 


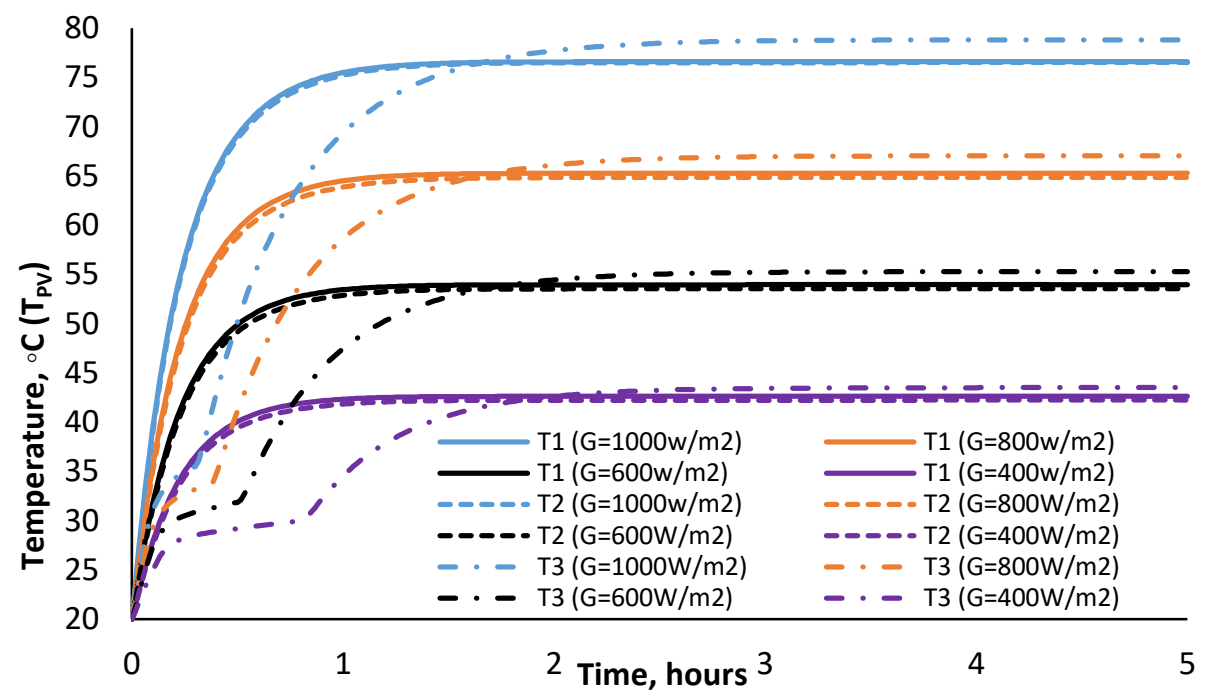

Figure 12: PV temperatures against three solar radiation levels

(Subscripts 1; 2; 3 refer to the standard PV system, the PV/TEG system and the PV/TEG/PCM system)

\subsection{Theoretical PV efficiencies and power output}

Fig. 13 represents the relationship between the PV conversion efficiencies $\left(\eta_{p v}\right)$ for the three systems under the various solar radiation levels. They were obtained based on data from the temperature profiles in Fig. 8 and Eq. 1. The corresponding PV power outputs $\left(\mathrm{E}_{\mathrm{pv}}\right)$ were subsequently calculated using Eq. 4 and plotted in Fig. 14. In both cases, the PV/TEG/PCM system performed much better than the others by achieving the highest $\eta_{p v}$ and $E_{p v}$ values during the initial 1.5 hours before dropping slightly in the later hours. For instance, under $1000 \mathrm{~W} / \mathrm{m}^{2}$ solar radiation, the PV/TEG/PCM system achieved 9.5\% more power than the normal PV system during the first 1.5 hours but did reduce to $1.8 \%$ by the end of the 5-hour period as summarised in Table 4.

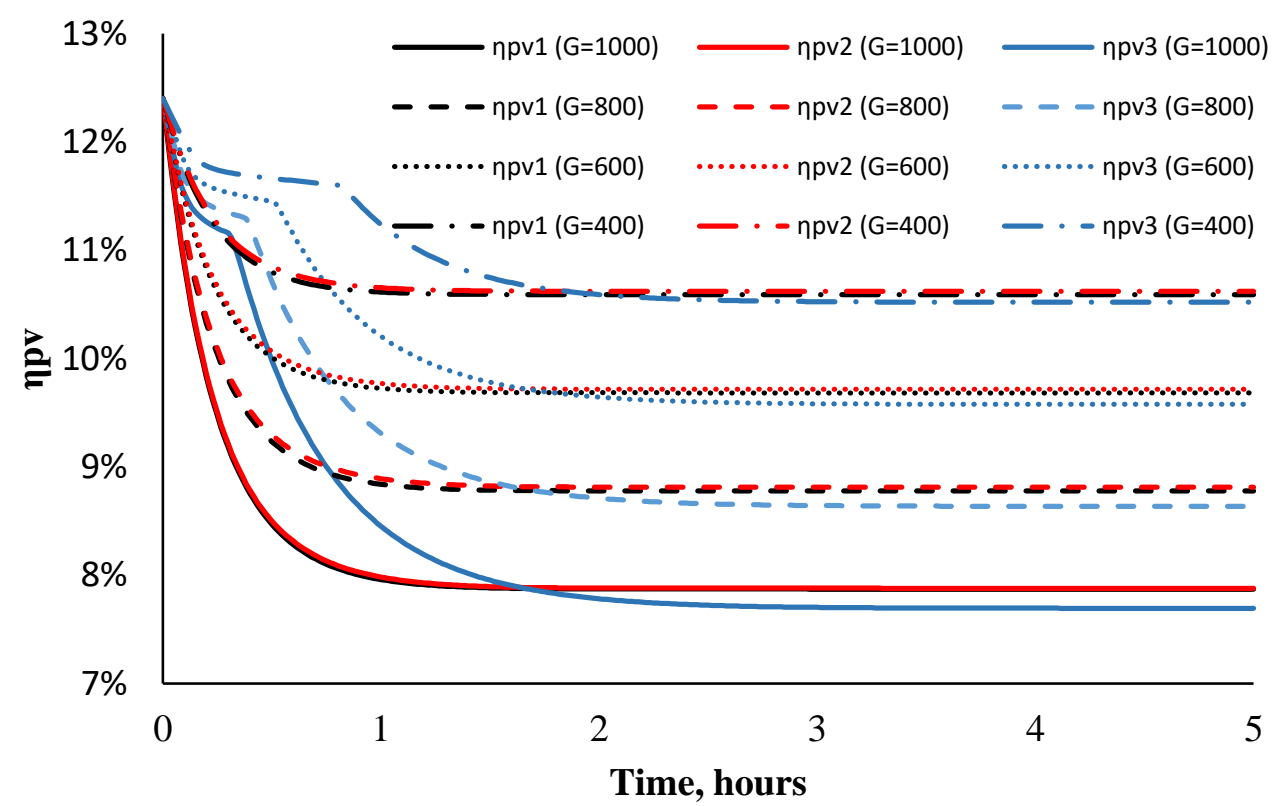

Figure 13: PV efficiency against solar radiation for the three systems 


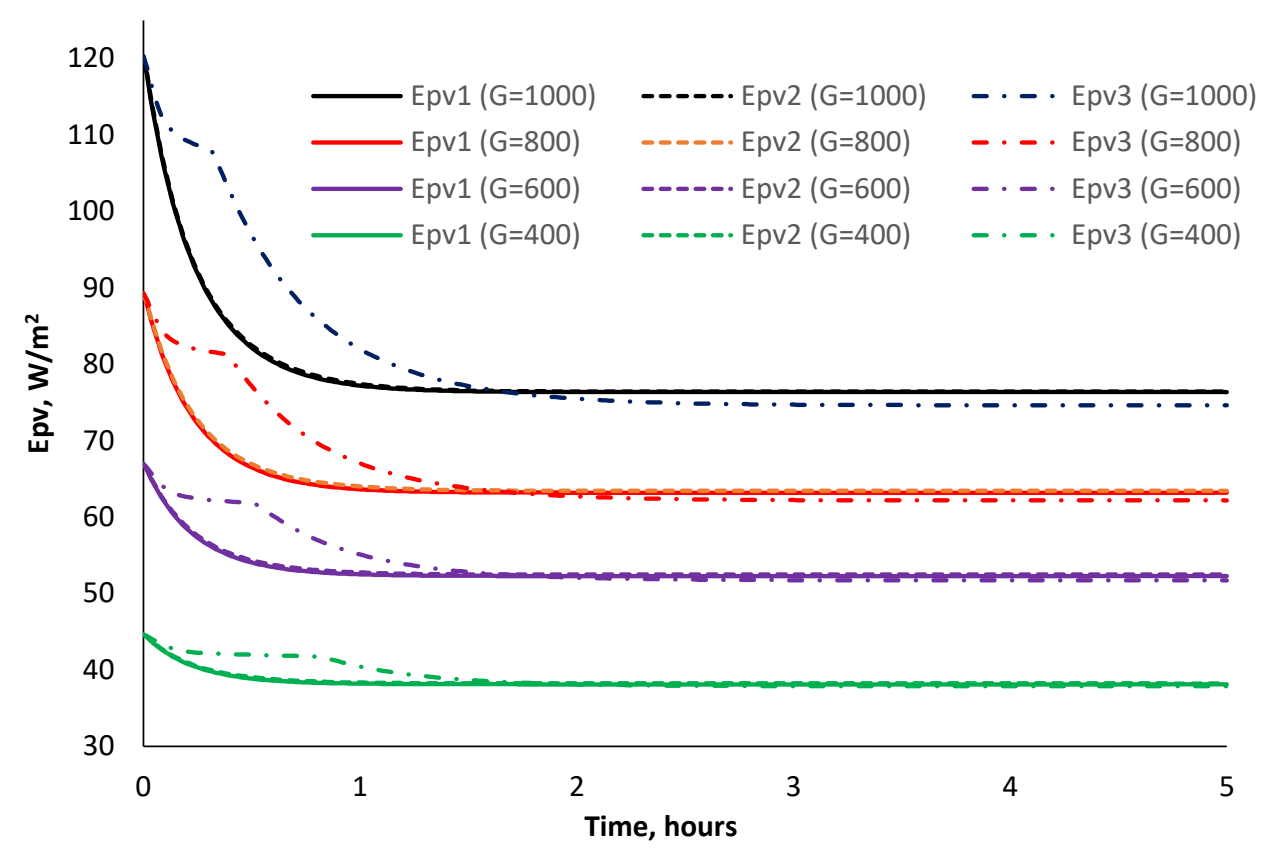

Figure 14: PV power output against solar radiation for the three systems

Table 4: Cumulative PV power output $\left(\mathrm{kW} / \mathrm{m}^{2}\right)$ over 1.5 hours and 5 hours

\begin{tabular}{llllll}
\hline $\begin{array}{l}\text { Solar } \\
\text { radiation }\end{array}$ & Time & PV & PV/TEG & PV/TEG/PCM & $\begin{array}{l}\text { Power } \\
\text { increase over } \\
\text { PV }(\%)\end{array}$ \\
\hline $1000 \mathrm{~W} / \mathrm{m}^{2}$ & $1.5 \mathrm{hrs}$. & 0.126 & 0.126 & 0.138 & $+9.5 \%$ \\
& $5 \mathrm{hrs.}$ & 0.393 & 0.394 & 0.400 & $+1.78 \%$ \\
& $1.5 \mathrm{hrs}$. & 0.101 & 0.102 & 0.109 & $+7.9 \%$ \\
& $500 \mathrm{~W} / \mathrm{m}^{2}$ & 0.322 & 0.324 & 0.328 & $+1.86 \%$ \\
& $1.5 \mathrm{hrs}$. & 0.082 & 0.082 & 0.087 & $+6.1 \%$ \\
& $500 \mathrm{~W} / \mathrm{m}^{2}$ & 0.265 & 0.266 & 0.269 & $+1.51 \%$ \\
& $1.5 \mathrm{hrs}$. & 0.059 & 0.059 & 0.062 & $+5.1 \%$ \\
& $500 \mathrm{~W} / \mathrm{m}^{2}$ & 0.192 & 0.193 & 0.195 & $+1.56 \%$ \\
\hline
\end{tabular}

\subsection{Theoretical TEG Power output}

The power outputs from the TEG in the PV/TEG and PV/TEG/PCM systems were examined separately. As presented in Fig. 15 and Fig. 16, the peak power outputs were obtained as $0.11 \mathrm{~W} / \mathrm{m}^{2}$ and $0.55 \mathrm{~W} / \mathrm{m}^{2}$ for the PV/TEG and PV/TEG/PCM systems respectively. By taking the maximum $E_{p v}$ as $110 \mathrm{~W} / \mathrm{m}^{2}$ (from Fig. 14), the ratio of $E_{\text {teg }} / E_{p v}$ becomes $0.5 \%$. This is relatively quite small as compared with the power output at normal operating condition for a standard PV system thus making contribution from the TEG insignificant. It therefore indicates that the gross enhanced power output for the integrated system was largely due to lowering of 
the peak PV temperature or enlarged temperature difference with the PCM layer. For instance, the peak differential temperature $(\Delta \mathrm{T})$ at $1000 \mathrm{~W} / \mathrm{m}^{2}$ solar radiation level, was $1.38 \mathrm{~K}$ for the $\mathrm{PV} / \mathrm{TEG} / \mathrm{PCM}$ as against $0.62 \mathrm{~K}$ for the PV/TEG system. This is evident from the graphs where higher solar radiation levels resulted in relatively larger $\Delta \mathrm{T}$ and consequently higher power output for the PV/TEG/PCM module.

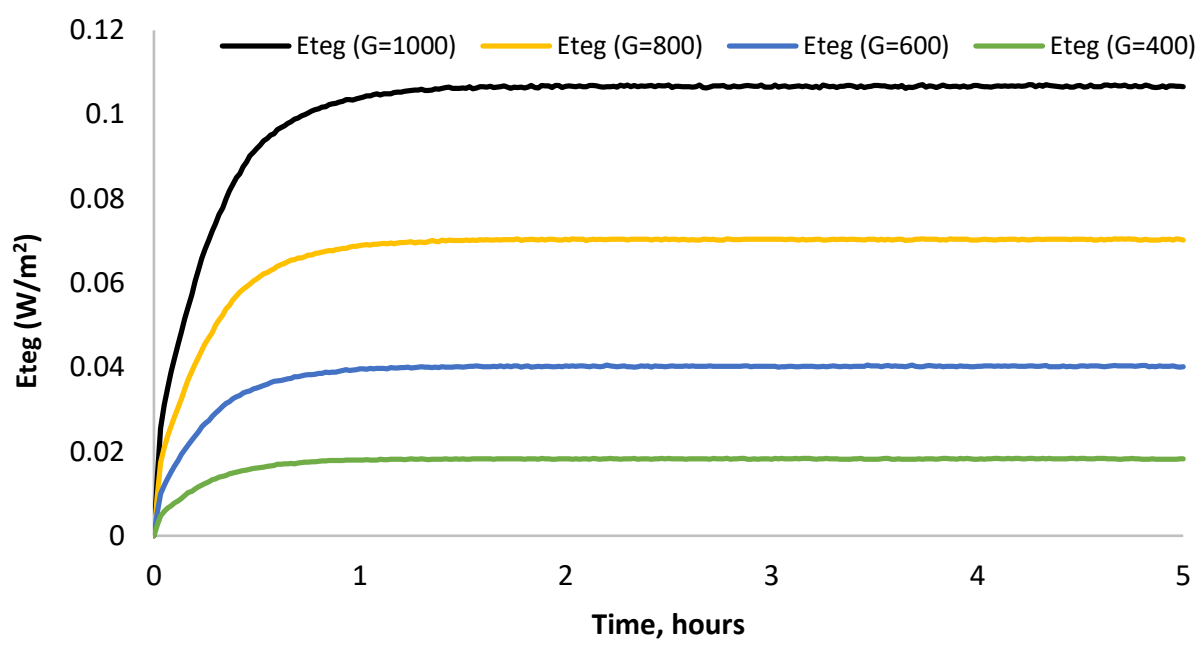

Figure 15: TEG power output against solar radiation in PV/TEG system

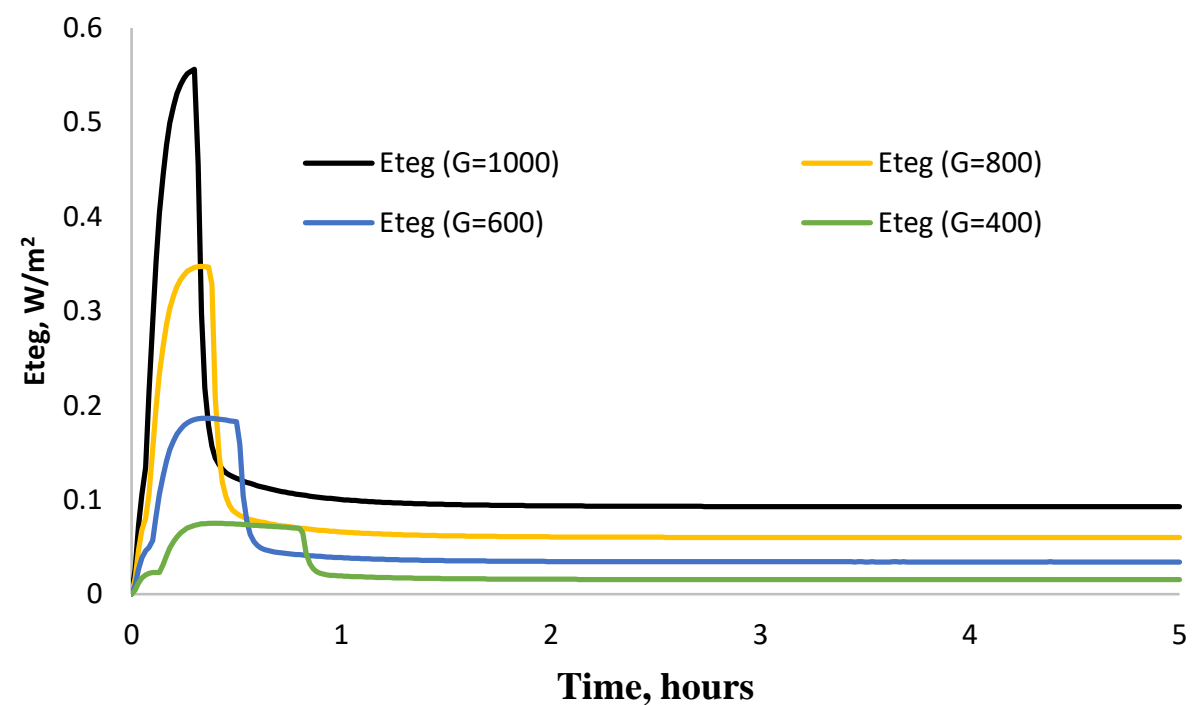

Figure 16: TEG power output against solar radiation in PV/TEG/PCM system

\subsection{Enhanced cooling strategies}

The power outputs from the TEGs were found to be quite small in Sec. 4.3 mainly due to low differential temperatures. In order to investigate the effect of different cooling strategies, simulations were conducted for three (3) scenarios covering natural convection by air, forced convection by air and forced convection by water with typical convection coefficients as 5 $\mathrm{W} / \mathrm{m}^{2} \mathrm{~K}, 100 \mathrm{~W} / \mathrm{m}^{2} \mathrm{~K}$, and $500 \mathrm{~W} / \mathrm{m}^{2} \mathrm{~K}$ respectively and for solar radiation of $1000 \mathrm{~W} / \mathrm{m}^{2}$ [45] The boundary conditions for the three systems were set identical at each time with the convection coefficient on the bottom surface as the only variable. 
Fig. 17 represents the temperature profiles for the three cases, and it is obvious that, the higher heat transfer convection values were more effective in reducing the peak temperatures. The PV/TEG/PCM system also achieved the highest differential temperature against the standard PV system (see Tab. 5) and was attributed to the insulation effect of the PCM layer which accounted for a much bigger share of the total thermal resistance. However, as shown in Fig. 18 and summarized in Tab. 6, the integrated PV/TEG/PCM system displayed some level of ineffectiveness as the cumulative power output dropped by $8.9 \%$ and $10 \%$ under the forced air and water sources respectively. The standard PV system which had good surface contact cooling factor effect achieved the most progressive cumulative power output trend with the higher convective heat transfer coefficients. It should however be noted that this was obtained through forced convection which would require additional power input.

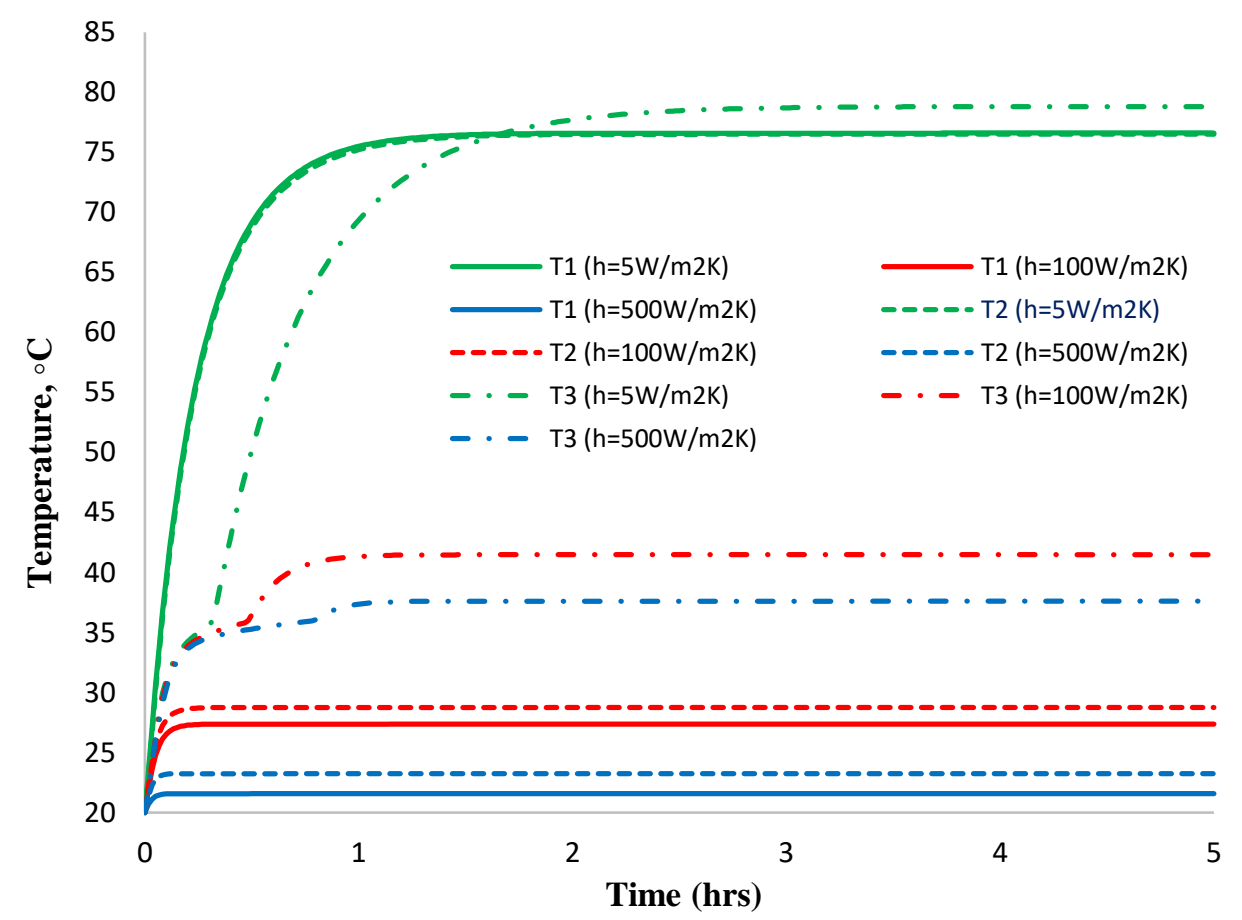

Figure 17: PV temperature for three convective heat transfer coefficient cases

Table 5: Peak PV temperature after thermal equilibrium

\begin{tabular}{|c|c|c|c|c|c|}
\hline $\begin{array}{l}\text { Cooling } \\
\text { sources }\end{array}$ & $\begin{array}{l}\text { Convective } \\
\text { heat transfer } \\
\text { coefficient }\end{array}$ & PV & PV/TEG & PV/TEG/PCM & $\begin{array}{l}\mathrm{PV} / \mathrm{TEG} / \mathrm{PCM} \\
\text { against } \mathrm{PV} \\
\text { system }(\Delta \mathrm{T})\end{array}$ \\
\hline Natural air & $\mathrm{h}=5 \mathrm{~W} / \mathrm{m}^{2} \mathrm{~K}$ & $76.60^{\circ} \mathrm{C}$ & $76.51{ }^{\circ} \mathrm{C}$ & $78.80{ }^{\circ} \mathrm{C}$ & $2.2 \mathrm{~K}$ \\
\hline Forced air & $\mathrm{h}=100 \mathrm{~W} / \mathrm{m}^{2} \mathrm{~K}$ & $27.37^{\circ} \mathrm{C}$ & $28.75^{\circ} \mathrm{C}$ & $41.48^{\circ} \mathrm{C}$ & $14.11 \mathrm{~K}$ \\
\hline $\begin{array}{l}\text { Forced } \\
\text { water }\end{array}$ & $\mathrm{h}=500 \mathrm{~W} / \mathrm{m}^{2} \mathrm{~K}$ & $21.58^{\circ} \mathrm{C}$ & $23.24{ }^{\circ} \mathrm{C}$ & $37.61^{\circ} \mathrm{C}$ & $16.03 \mathrm{~K}$ \\
\hline
\end{tabular}




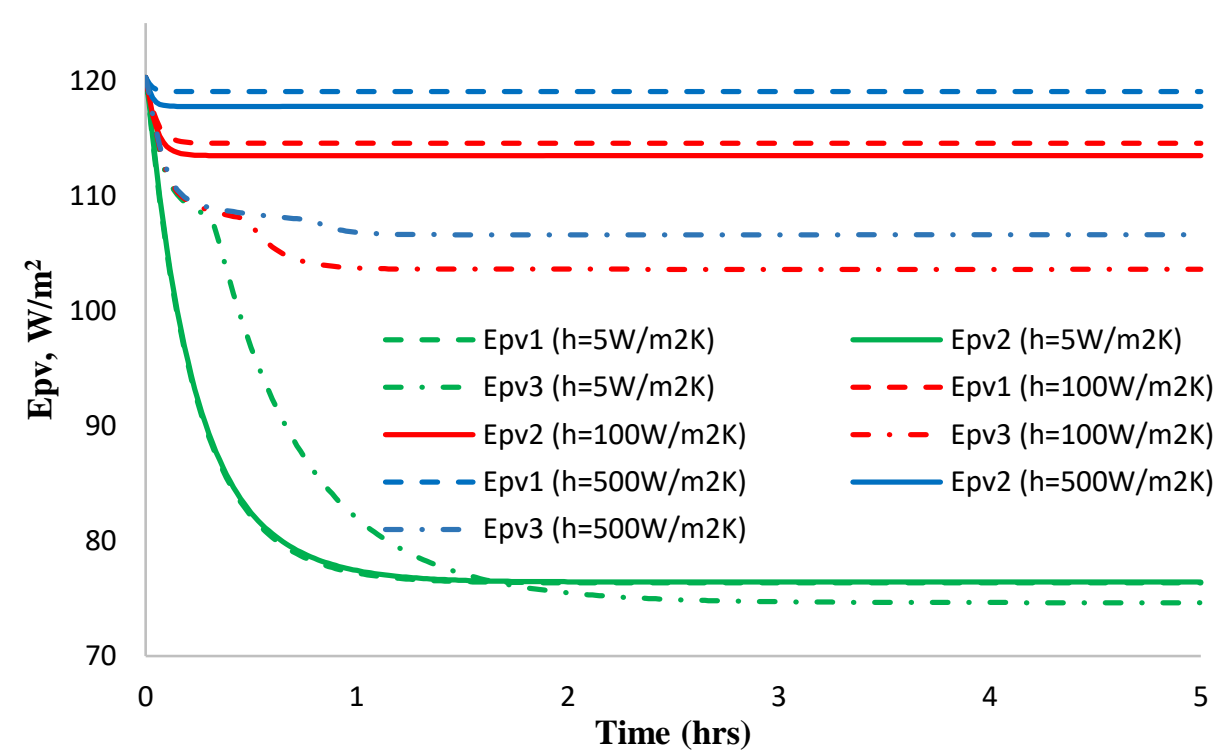

Figure 18: PV power output for different convective heat transfer coefficients

Table 6: Cumulative PV power output in $\mathrm{kW} / \mathrm{m}^{2}$ for the three cases

\begin{tabular}{llllll}
\hline $\begin{array}{l}\text { Cooling } \\
\text { sources }\end{array}$ & $\begin{array}{l}\text { Convective } \\
\text { transfer } \\
\text { coefficient }\end{array}$ & PV & PV/TEG & PV/TEG/PCM & Differential \% \\
\hline $\begin{array}{l}\text { Natural } \\
\text { air }\end{array}$ & $5 \mathrm{~W} / \mathrm{m}^{2} \mathrm{~K}$ & 0.393 & 0.394 & 0.400 & $1.9 \%$ \\
$\begin{array}{l}\text { Forced } \\
\text { air }\end{array}$ & $100 \mathrm{~W} / \mathrm{m}^{2} \mathrm{~K}$ & 0.573 & 0.567 & 0.522 & $-8.9 \%$ \\
$\begin{array}{l}\text { Forced } \\
\text { water }\end{array}$ & $500 \mathrm{~W} / \mathrm{m}^{2} \mathrm{~K}$ & 0.595 & 0.588 & 0.535 & $-10.0 \%$ \\
\hline
\end{tabular}

\subsection{Different thicknesses of the PCM layer}

The impact of the different thicknesses of PCM layer (ranging from $2.5 \mathrm{~mm}$ to $20 \mathrm{~mm}$ ) on the performance of the PV/TEG/PCM system was also analysed based on the boundary conditions in Tab. 7. The temperature profiles are shown in Fig. 19. Even though there were minor differences between the peak temperatures, the thicker layers were able to moderate the temperatures for much longer period than the thinner ones due to the larger insulation effect. They however contributed to reduction in cumulative power output as shown in Fig. 20 and was attributed to poor heat dissipation rate from the PCM layer.

Table 7: Boundary conditions

\begin{tabular}{lll}
\hline & Top surface & Bottom surface \\
\hline Heat Transfer Coefficient $\left(\mathrm{W} / \mathrm{m}^{2} \mathrm{~K}\right)$ & 10 & 5 \\
Free Stream Temperature $(\mathrm{K})$ & 293 & 293 \\
Solar radiation $\left(\mathrm{W} / \mathrm{m}^{2}\right)$ & 1000 & $\mathrm{n} / \mathrm{a}$ \\
\hline
\end{tabular}




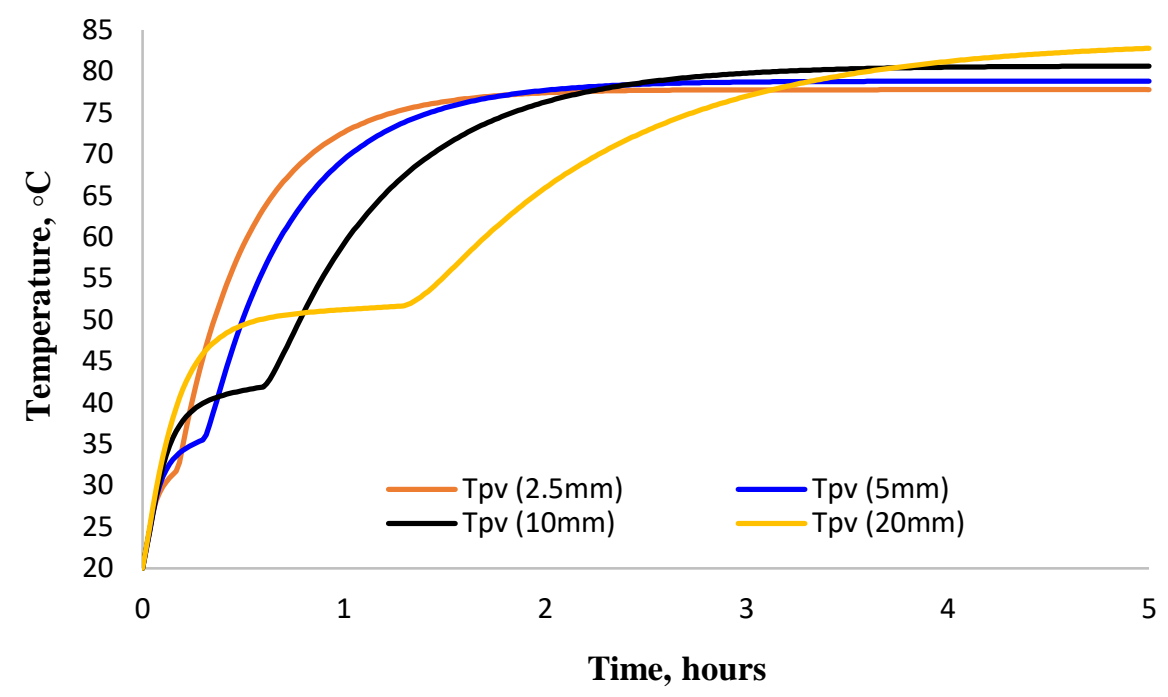

Figure 19: PV temperature for various thickness of PCM layer

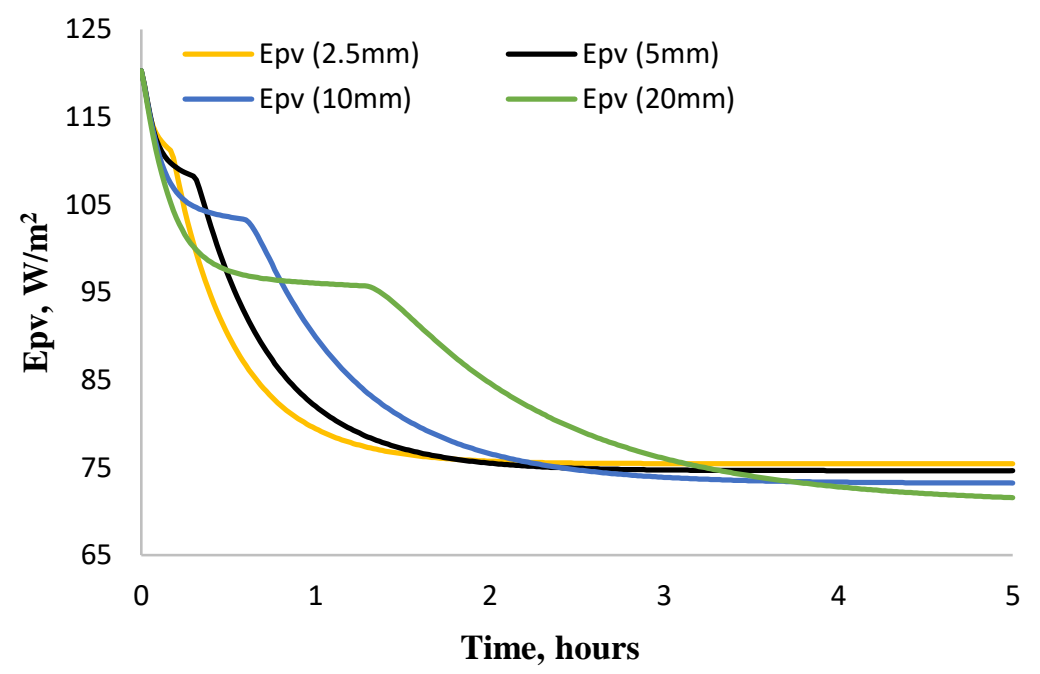

Figure 20: PV power output for various thickness of PCM layer

\subsection{Experimental temperature profiles for standard PV, PV/TEG and PV/TEG/PCM systems}

Fig. 21 represents the PV back temperature profiles for the standard PV, PV/TEG and the $\mathrm{PV} / \mathrm{TEG} / \mathrm{PCM}$ systems. It can be observed that, there was about 2-hour time lag before the PV/TEG/PCM system reached the same temperature level as the standard PV system. This means that the PV/TEG/PCM system was able to significantly reduce the PV temperature during the first 2 hours as compared with the standard PV system. The reduced PV temperature represents an enhanced PV efficiency. Based on the PV system with $\eta$ equal to $12 \%$ at $25^{\circ} \mathrm{C}$, PV efficiencies can be calculated for the standard PV and the PV/TEG/PCM systems using Eq. 4. As summarised in Tab. 8 , the PV/TEG/PCM was able to generate $6.7 \%$ and $4.5 \%$ more energy than the standard PV system in the first 1 hour and 2 hours respectively. 


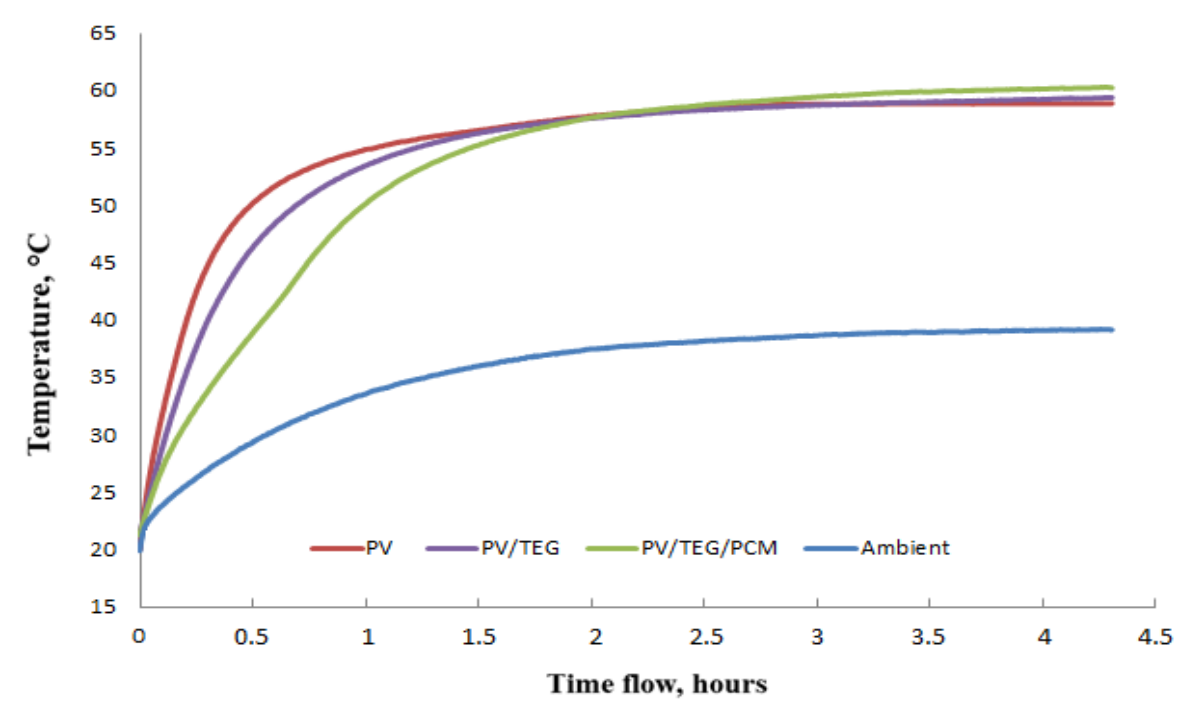

Figure 21: PV back temperature for standard PV, PV/TEG and PV/TEG/PCM systems

Table 8: Calculated enhanced PV efficiency

\begin{tabular}{lllll}
\hline Efficiency & PV & PV/TEG/PCM & Change of $\eta$ & Change \% \\
\hline 1 hr avg. $\eta$ & $10.7 \%$ & $11.5 \%$ & $+0.7 \%$ & $+6.7 \%$ \\
2 hrs avg. $\eta$ & $9.8 \%$ & $10.3 \%$ & $+0.4 \%$ & $+4.5 \%$ \\
\hline
\end{tabular}

\subsection{Experimental TEG output}

The differential temperature $(\Delta \mathrm{T})$ profiles for the TEG are shown in Fig. 22. It is noticeable that in the PV/TEG/PCM system, the $\Delta \mathrm{T}$ was very much enlarged during the phase change period before gradually decreasing. The peak $\Delta \mathrm{T}$ was $1.6 \mathrm{~K}$ as against $0.9 \mathrm{~K}$ for the PV/TEG system thus indicating that the PCM had positive effect on the enlargement of the $\Delta \mathrm{T}$. The TEG open circuit voltage can also be used as an index for the output power. In Fig. 23, the PV/TEG/PCM system was able to deliver a peak open circuit voltage of $0.75 \mathrm{~V}$ as compared with $0.38 \mathrm{~V}$ for the PV/TEG system. The relatively small voltage indicate that the corresponding power output was small and therefore no actual measurement of the circuit electric load was carried out. However, the conversion efficiency of the TEG module $\left(\eta_{\text {teg }}\right)$ was obtained by using Eq. 5 .

By adopting figure of merit $Z=0.004 \mathrm{~K}^{-1}$, the $\mathrm{T}_{\text {teg }}$ was taken as the average value of $\mathrm{T}_{\text {hot }}(310$ $\mathrm{K}$ ) and $\mathrm{T}_{\text {cold }}(308.4 \mathrm{~K})$ to obtain $\eta_{\text {teg }}$ as $0.1 \%$. The corresponding heat flux was $243 \mathrm{~W} / \mathrm{m}^{2}$ and therefore the TEG output power was $0.24 \mathrm{~W} / \mathrm{m}^{2}$ for an ideal temperature condition. 


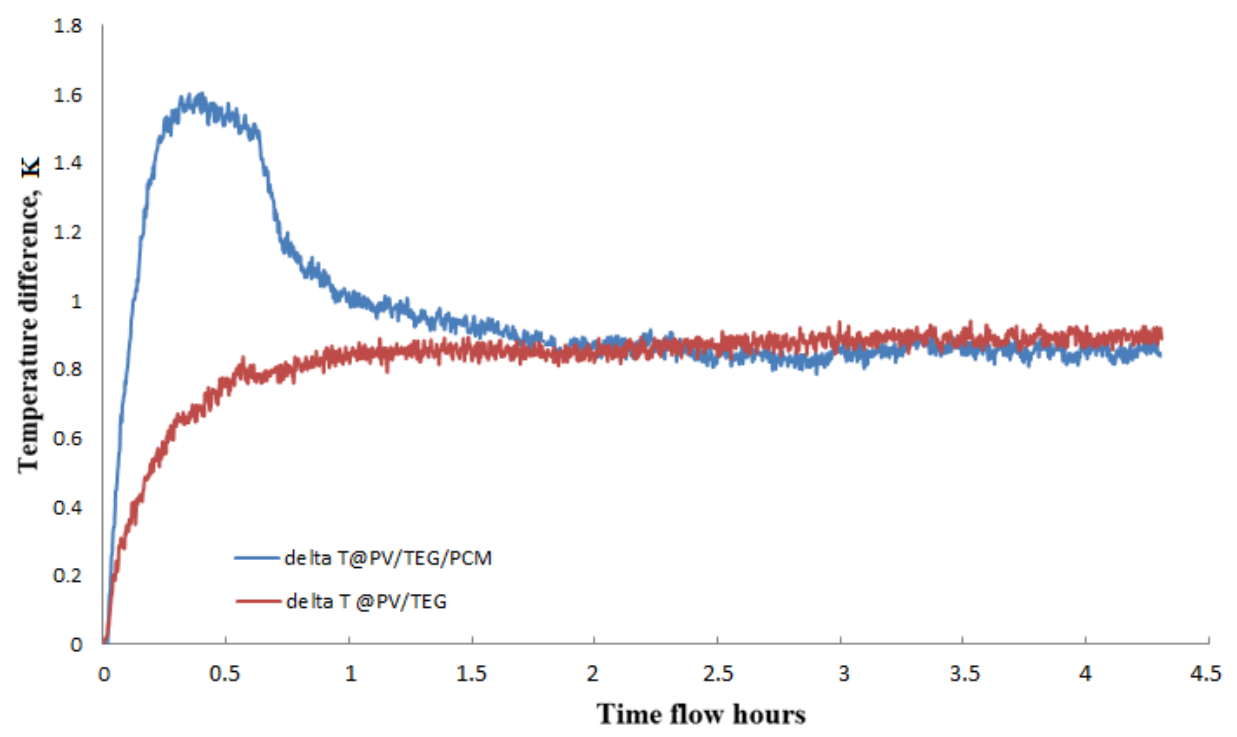

Figure 22: Differential temperature across the hot and cold surfaces of the TEGs

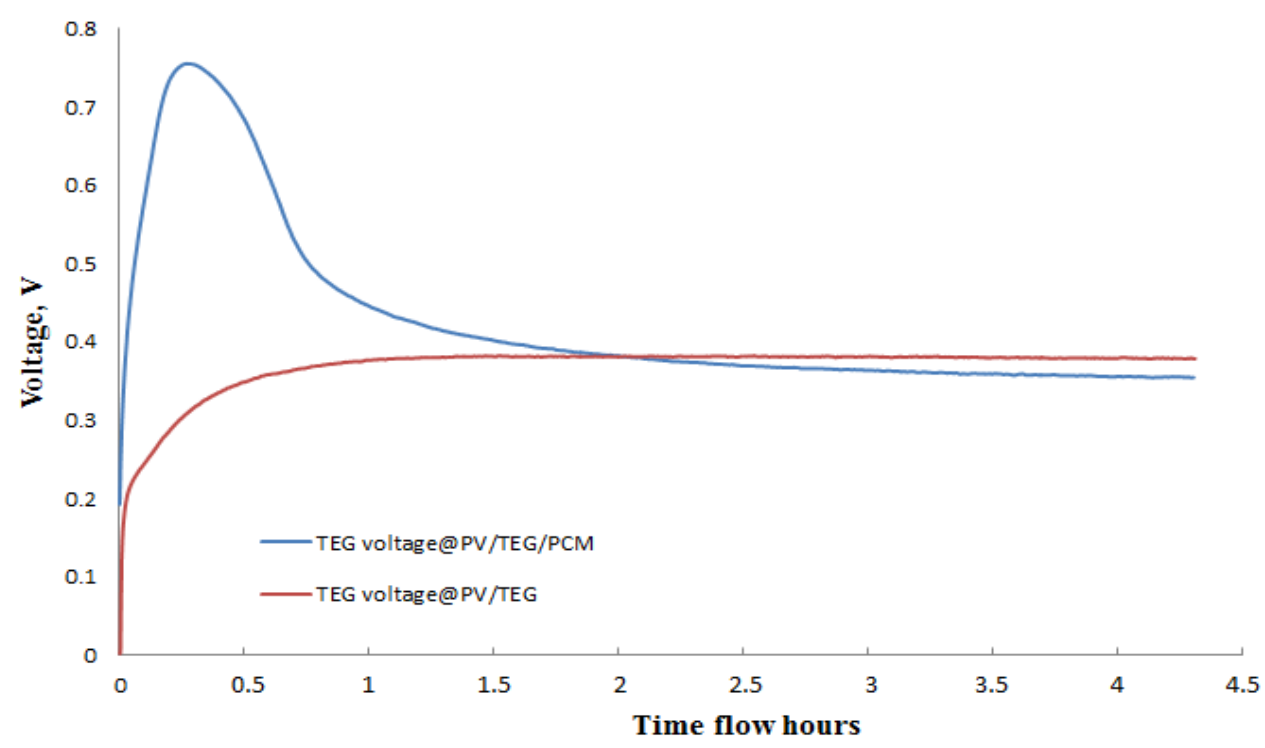

Figure 23: TEG voltage output for PV/TEG/PCM system and PV/TEG system

\subsection{Experimental validation}

In order to validate the model, numerical simulations were carried out based on the experimental data and boundary conditions. The initial heat flux recorded on the surface of the $\mathrm{PV}$ was $520 \mathrm{~W} / \mathrm{m}^{2}$ with an average efficiency of around $10 \%$ and therefore the power output is equal to; $E_{p v}=520 \mathrm{~W} / \mathrm{m}^{2} * 10 \%=52 \mathrm{~W} / \mathrm{m}^{2}$.

By considering this part of the energy which was not converted into a form of thermal energy, a source term for the cell zone " $P V$ " was set so that the equivalent amount of heat could be removed from the simulated system. Since in the simulation the value was based on a volume scale, and the thickness of the PV layer $\Delta L_{p v}=1.5 \mathrm{~mm}$, the source term was obtained with Eq. 12 as shown below;

$$
\text { "PV" }=E_{p v} / \Delta L_{p v}=-34666 \mathrm{~W} / \mathrm{m}^{3}
$$


Convective heat transfer coefficients on the glazing front surface and the PCM bottom surface were set as $10 \mathrm{~W} / \mathrm{m}^{2} \mathrm{~K}$ and $5 \mathrm{~W} / \mathrm{m}^{2} \mathrm{~K}$ respectively since the empirical correlations revealed that the top surface was double that of the bottom surface for horizontal plate in natural convection [46]. The global solar irradiation perpendicularly on the glazing front surface was set as 520 $\mathrm{W} / \mathrm{m}^{2}$ just as it was in the experiment. The ambient temperature in the simulation (in unit of $\mathrm{K}$ ) adopted a user defined function (UDF) as an input to best reflect the condition in the experiment, which is shown in the piecewise function below as:

$$
\mathrm{T}_{\infty}=\left\{\begin{array}{cr}
a_{1} t^{4}+a_{2} t^{3}+a_{3} t^{2}+a_{4} t+293.18 & (0 \leq \mathrm{t}<500 \mathrm{~s}) \\
b_{1} t^{4}+b_{2} t^{3}+b_{3} t^{2}+b_{4} t+295.22 & (500 \mathrm{~s} \leq t \leq 13000 \mathrm{~s}) \\
312 & (13000 \mathrm{~s}<t \leq 18000 \mathrm{~s})
\end{array}\right.
$$

Where $a_{1}=-2.47899693076048 \times 10^{-10}, a_{2}=3.05048603252422 \times 10^{-7}$,

$$
\begin{array}{ll}
a_{3}=1.35304895072963 \times 10^{-4}, & a_{4}=0.0310182898601852, \\
b_{1}=-6.11665582569822 \times 10^{-16}, & b_{2}=3.00499150094059 \times 10^{-11}, \\
b_{3}=5.57834641633573 \times 10^{-7}, & b_{4}=0.0048058312375332 .
\end{array}
$$

The ambient temperature expressed by Eq. 13 was plotted together with the ambient temperature recorded in the experimental test described in 3.4 and it showed that the UDF was able to give accurate computational ambient temperature as boundary conditions for the simulation works.

The temperature profiles for the PV back surface $\left(T_{p v}\right)$, TEG back surface $\left(T_{\text {teg }}\right)$ and PCM back surface $\left(T_{\mathrm{pcm}}\right)$ were simulated and the results presented in Fig. 24. It can be observed that initially both $\mathrm{T}_{\mathrm{pv}}$ and $\mathrm{T}_{\text {teg }}$ did increase rapidly before gradually stabilizing at $62.23{ }^{\circ} \mathrm{C}$ and $62.03{ }^{\circ} \mathrm{C}$ respectively. These values were also found to be close to the experimental results $\left(\mathrm{T}_{\mathrm{pv}}=60.4{ }^{\circ} \mathrm{C}\right.$ and $\left.\mathrm{T}_{\text {teg }}=59.6{ }^{\circ} \mathrm{C}\right)$. The temperature difference between the two ceramic layers of the TEG was negligible due to their respective small thermal resistances, thus confirming the setting of $E_{t e g}=0$ in the simulation as reasonable. The temperature difference between $\mathrm{T}_{\text {teg }}$ and $\mathrm{T}_{\mathrm{pcm}}$ was found to be relatively large due to the relatively low thermal conductivity of the PCM.

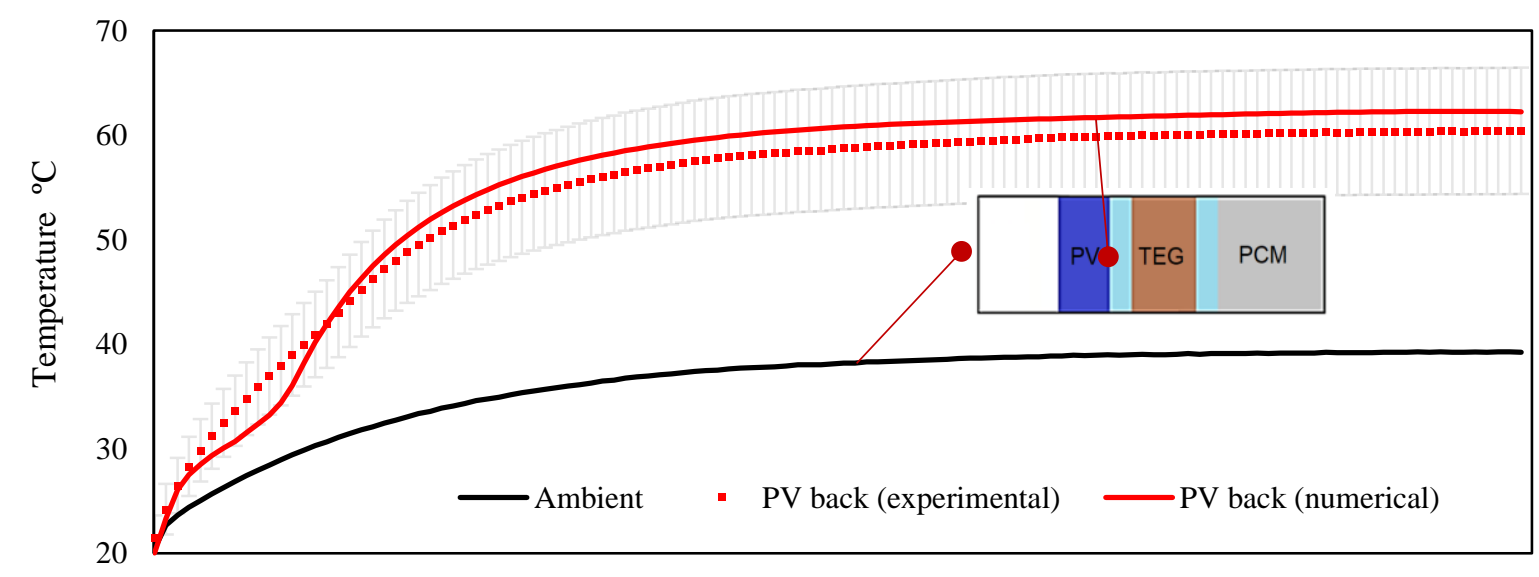



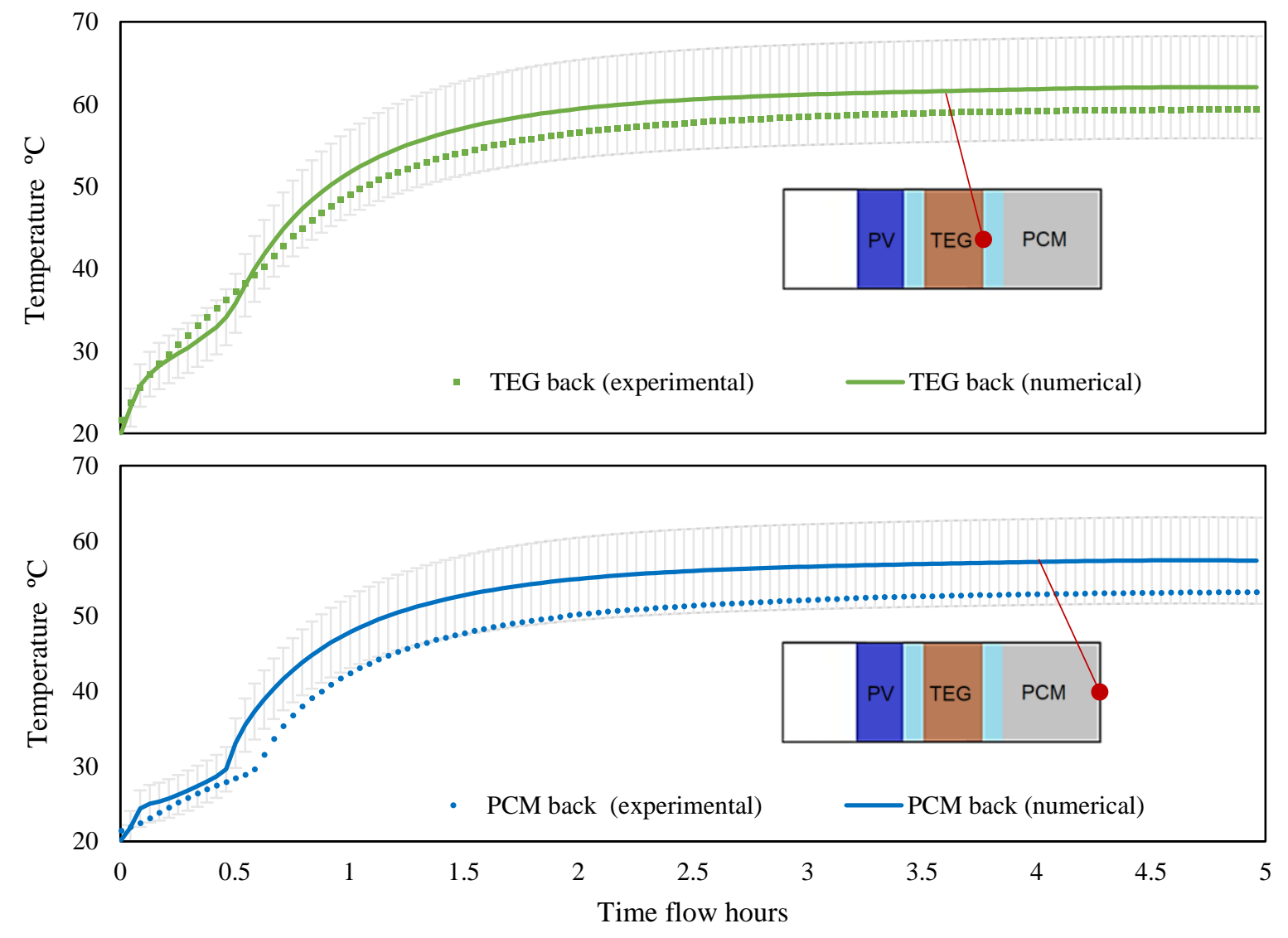

Figure 24: Simulated and experimental temperature profiles for PV/TEG/PCM system. Error bars at $\pm 10 \%$.

There were however minor differences between the simulated results and the experimental results in Fig. 24. For instance, during the phase change period, it could be noticed that the temperature curbing effect of the PCM was better regulated in the experiment than in the simulated result. This was attributed to the contact resistance which existed between the PCM layer and TEG cold side. The differential TEG temperature for the simulated result was also smaller and was attributed to the contact resistances within the interface gaps between the back of the PV /TEG ceramic 1 and TEG ceramic $2 / \mathrm{PCM}$. This was inevitable since the thermocouples were installed in the interfaces. However, the experimental results showed that the differential TEG temperature between ceramic layer 1 and ceramic layer 2 was also small and could be neglected. Overall, the developed model has been validated by the experimental data and therefore can be used to conduct reliable simulations.

\subsection{CONCLUSIONS AND FUTURE WORKS}

This study was conducted to assess the potential and viability of an integrated PV/TEG/PCM power system. For the purpose of comparison, standard PV and PV/TEG systems were also analysed. The study developed a numerical model for thermal simulations of the integrated system. The results showed good agreement between the predicted results and experimental measurements. The results showed that despite the insulation effect of the PCM layer, the integrated PV/TEG/PCM system was able to achieve about $9.5 \%$ power output more than the other two systems during the initial 1.5 hours period. Analysis of different cooling strategies covering both natural and forced convection modes of cooling also revealed that the standard PV system achieved the highest cumulative power output i.e. $51.4 \%$ increase with forced 
convection mode of cooling but would however require additional power input to drive accessories such as pumps and fans. The effect of different thicknesses of PCM layer on output power was also evaluated. The observation was that the thicker PCM layers were more effective in lowering the PV temperature for a longer period. However, their relatively larger insulation effect contributed to reduction in power output due to poor heat dissipation rates during the stage of thermal equilibrium. In general, the study has shown some level of potential in the concept of integrated PV/TEG/PCM power system but recognises the limitations of current commercial TEGs as power conversion devices. Further optimisation and experimental evaluation are however being recommended towards the establishment of the full technical and scientific boundaries.

\section{REFERENCES}

1. Tian, Y., Zhao, C.Y., A review of solar collectors and thermal energy storage in solar thermal applications. Applied Energy, 2013, 104: p. 538-553.

2. Radziemska, E. and Klugmann, E., Thermally affected parameters of the currentvoltage characteristics of silicon photocell. Conversion and Management, 2002. 43: p. 1889-1900.

3. Ali H.A. Al-Waelia, K. Sopiana, Hussein A. Kazemb, Miqdam T. Chaichanc, Photovoltaic/Thermal (PV/T) systems: Status and future prospects. Renewable and Sustainable Energy Reviews, 2017, 77, p.109-130.

4. Yazdanifard, F. Mehran Ameri, Exergetic advancement of photovoltaic/thermal systems (PV/T): A review. Renewable and Sustainable Energy Reviews, 2018, 97: p. 529-553.

5. Du, D., Darkwa, J., Kokogiannakis, G., Thermal management systems for Photovoltaics (PV) installations: A critical review. Solar Energy, 2013. 97(0): p. 238-254.

6. Du, K., Calautit, J., Wang, Z., Wu, Y., Liu, H., A review of the applications of phase change materials in cooling, heating and power generation in different temperature ranges. Applied Energy, 2018, 220: p. 242-273.

7. Rodrigo, P.M., Valera, A., Fernández, E.F., Almonacid, F.M., Performance and economic limits of passively cooled hybrid thermoelectric generator-concentrator photovoltaic modules. Applied Energy, 2019, 238: p. 1150-1162.

8. He, W., Zhou, J., Hou, J., Chen, C., Ji, J., Theoretical and experimental investigation on a thermoelectric cooling and heating system driven by solar. Applied Energy, 2013, 107: p. 89-97.

9. Kwan, T., Wu, X., Power and mass optimization of the hybrid solar panel and thermoelectric generators. Applied Energy, 2016, 165: p. 297-307.

10. Wenham, S.R., M.A. Green, and M.E. Watt, Applied Photovoltaics. 2nd ed. 2006, London: Routledge.

11. Iliceto, A. and R. Vigotti, The largest PV installation in Europe: perspectives of multimemawatt $P V$. Renewable Energy, 1998. 15: p. 48-53.

12. Araki, K., H. Uozumi, and M. Yamaguchi. A simple passive cooling structure and its heat analysis for 500 X concentrator PV module. in 29th IEEE 2002.

13. Zakharchenko, R., Photovoltaic solar panel for a hybrid PV/thermal system. Solar Energy Materials and Solar Cells, 2004. 82(1-2): p. 253-261.

14. Hegazy, A.A., Comparative study of the performances of four photovoltaic/thermal solar air collectors. Energy Conversion and Management, 2000. 41(8): p. 861-881.

15. Li, Z., Boehm, R.F., Wang, Y., Halford, C., Sun, Y., Water immersion cooling of PV cells in a high concentration system. Solar Energy Materials and Solar Cells, 2011. 95(2): p. 538-545.

16. Royne, A. and C.J. Dey, Design of a jet impingement cooling device for densely packed PV cells under high concentration. Solar Energy, 2007. 81(8): p. 1014-1024. 
17. Garimella, S.V., and Sobhan, C.B, Recent advances in the modeling and applications of nonconventional heat pipes. Advances in Heat Transfer, 2001. 35: p. 249-308.

18. Huang, M.J., P.C. Eames, and B. Norton, Thermal regulation of building-integrated photovoltaics using phase change materials. International Journal of Heat and Mass Transfer, 2004. 47(12-13): p. 2715-2733.

19. Hasan, A., Mccormack, S.J., Huang, M.J., and Norton, B., Evaluation of phase change materials for thermal regulation enhancement of building integrated photovoltaics. Solar Energy, 2010, 84: p. 1601-1612.

20. Ho, C.J., Tanuwijava, A.O., and Lai, C.M., Thermal and electrical performance of a BIPV integrated with a microencapsulated phase change material layer. Energy and Buildings, 2012, 50: p. 331-338.

21. Stropnik, R and Stritih, U., Increasing the efficiency of PV panel with the use of PCM, Renewable Energy. 2016, 97: p. 671-679.

22. Chandela, S. S., Agarwalb, T., Review of cooling techniques using phase change materials for enhancing efficiency of photovoltaic power systems. Renewable and Sustainable Energy Reviews, 2017, 73: p. 1342-1351.

23. Hsu, C., Huang, G., Chu, H., Yu, B., Yao, D., Experiments and simulations on lowtemperature waste heat harvesting system by thermoelectric power generators. Applied Energy, 2011, 88: p. 1291-1297.

24. Gou, X., Xiao, H., Yang, S., Modeling, experimental study and optimization on lowtemperature waste heat thermoelectric generator system. Applied Energy, 2010, 87: p. 3131-3136.

25. Yodovard, P., Khedari, J., Hirunlabh, J., The potential of waste heat thermoelectric power generation from diesel cycle and gas turbine cogeneration plants. Energy Sources, 2001, 23: p. 213-224.

26. Amatya, R. and R.J. Ram, Solar Thermoelectric Generator for Micropower Applications. Journal of Electronic Materials, 2010. 39(9): p. 1735-1740.

27. Olsen, M.L., Warren, E.L., Parilla, P.A., Toberer, E.S., Kennedy, C.E., Snyder, G.J., Firdosy, S.A., Nesmith, B., Zakutayev, A., Goodrich, A., Turchi, C.S., Netter, J., Gray, M.H., Ndione, P.F., Tirawat, R., Baranowski, L.L, Gray, A., Ginley, D.S., A Hightemperature, High-efficiency Solar Thermoelectric Generator Prototype. Energy Procedia, 2014. 49: p. 1460-1469.

28. Van Sark, W., Feasibility of photovoltaic-thermoelectric hybrid modules. Applied Energy, 2011. 88(8): p. 2785-2790.

29. Li, Y., Yu, H., Su, B., Shang, Y., Hybrid Micropower Source for Wireless Sensor Network. IEEE Sensor's Journal, 2008. 8(6).

30. Cui, T., Xuan, Y., Li, Q., Design of a novel concentrating photovoltaic-thermoelectric system incorporated with phase change materials. Energy Conversion and Management, 2016, 112: p. 49-60.

31. Kazemian, A., Salari, A., Hakkaki-Fard, A., Ma, T., Numerical investigation and parametric analysis of a photovoltaic thermal system integrated with phase change material. Applied Energy, 2019, 238: p. 734-746.

32. Yuan, W., Ji, J., Modjinou, M., Zhou, F., Li, Z., Song, Z., Huang, S., Zhao, X., Numerical simulation and experimental validation of the solar photovoltaic/thermal system with phase change material. Applied Energy, 2018, 232: p. 715-727.

33. Ma, T., Zhao, J., Li, Z., Mathematical modelling and sensitivity analysis of solar photovoltaic panel integrated with phase change material. Applied Energy, 2018, 228: p. 1147-1158.

34. Babu, C., Ponnambalam, P., The role of thermoelectric generators in the hybrid PV/T systems: A review. Energy Conversion and Management, 2017, 151: p. 368-385. 
35. Li, G., Shittu, S., Diallo, T., Yu, M., Zhao, X., Ji, J., A review of solar photovoltaicthermoelectric hybrid system for electricity generation. Energy, 2018, 158: p. 41-58.

36. Huen, P., Daoud, W., Advances in hybrid solar photovoltaic and thermoelectric generators, Renewable and Sustainable Energy Reviews. 2017, 72: p. 1295-1302.

37. Darkwa, J., O. Su, and T. Zhou, Development of non-deform micro-encapsulated phase change energy storage tablets. Applied Energy, 2012. 98: p. 441-447.

38. Baranowski, L., G. Snyder, and E. Toberer, Effective thermal conductivity in thermoelectric materials. Journal of Applied Physics, 2013.

39. Florian Romary, A.C., Sebastien Jacques, Ambroise Schellmanns, Thermal modelling to analyze the effect of cell temperature on PV modules energy efficiency. 2011.

40. Torres Lobera, D. and S. Valkealahti, Dynamic thermal model of solar PV systems under varying climatic conditions. Solar Energy, 2013. 93: p. 183-194.

41. Evans, D. and L. Florschuetz, Cost studies on terrestrial photovoltaic power systems with sunlight concentration. Solar Energy, 1977. 19(3): p. 255-262.

42. Rowe, D.M., CRC Handbook of Thermoelectrics, in Introduction, D.M. Rowe, Editor. 1995, CRC Press: Boca Raton.

43. Darkwa, J. and SU, O., Thermal simulation of composite high conductivity laminated microencapsulated phase change material (MEPCM) board. Applied Energy, 2012. 95: p. 246-252.

44. Krauter, S. and A. Preiss. Comparison of module temperature measurement methods. in Photovoltaic Specialists Conference (PVSC), 2009 34th IEEE. 2009

45. Annaratone, D., Engineering Heat Transfer. 2010, Berlin: Springer.

46. Bayazitoglu, Y. and M.N. Ozisik, Elements of Heat Transfer 1988, Singapore: McGrawHill 